\title{
Sedimentology of the Lower Cretaceous at Kikutodden and Keilhaufjellet, southern Spitsbergen: implications for an onshore-offshore link
}

\author{
Sten-Andreas Grundvåga ${ }^{\mathrm{a}}$ \& Snorre Olaussen ${ }^{\mathrm{b}}$

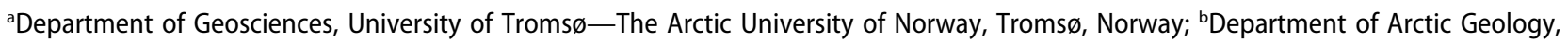 \\ University Centre in Svalbard, Longyearbyen, Norway
}

\begin{abstract}
Detailed sedimentological investigations of the Lower Cretaceous succession of southernmost Spitsbergen indicate deposition during a long-term fall and rise in relative sea level. The Rurikfjellet Formation shows an overall regressive development and consists of offshore deposits grading upwards into progradationally stacked shoreface parasequences. The overlying Helvetiafjellet Formation shows a two-fold division reflecting an overall transgressive development. The lower Festningen Member represents a lateral extensive sandstone sheet that was deposited in a braid plain setting with sediment dispersal to the south-east. The unit also includes a lower Barremian subaerial unconformity at its base, demonstrating that uplift and shelf erosion also took place in southern Spitsbergen. Clinoforms observed in seismic data from, amongst others, the Lower Cretaceous in the western Bjarmeland Platform suggest a potential link between the onshore unconformity and the offshore clinoforms. The Festningen Member is capped by a coaly shale unit that represents an expansion surface which marks a change into a high-accommodation distributary fluvial system of the overlying and heterolithic Glitrefjellet Member. The overall transgressive development recorded in the Helvetiafjellet Formation eventually resulted in a marine flooding that eroded and drowned the delta plain depositing an offshore mudstone unit, 5-10 $\mathrm{m}$ in thickness, that marks the reestablishment of open marine shelf conditions in the basal part of the Carolinefjellet Formation. The succeeding sand-rich part of the Carolinefjellet Formation contain abundant hummocky cross-stratified sandstones deposited in an inner shelf setting, and therefore represents renewed shoreline progradation onto the shallow subaqueous shelf.
\end{abstract}

\section{KEYWORDS}

Svalbard; Helvetiafjellet formation; Rurikfjellet formation; lowstand wedge; regressive-transgressive sequences

\section{ABBREVIATIONS}

$\mathrm{BI}$ : bioturbation index; FA: facies associations; HALIP: High Arctic Large Igneous Province; HCS: hummocky cross-stratification; PS: parasequence; SU: subaerial unconformity

\section{Introduction}

The Arctic archipelago of Svalbard, located on the north-western corner of the Barents Shelf (Fig. 1), displays a several kilometres thick package of sedimentary strata that ranges from Devonian to Eocene in age. Thanks to sparse vegetation and glacial erosion, large parts of the succession are well exposed along valley sides and coastal cliffs. Mesozoic strata are particularly well preserved in the archipelago. Throughout most of the Mesozoic, Svalbard formed part of a large, slowly subsiding intracratonic basin that was covered by a shallow epicontinental sea (Steel Worsley 1984). The Lower Cretaceous is assigned to the Adventdalen Group and comprises, in ascending stratigraphic order, the Rurikfjellet, Helvetiafjellet and Carolinefjellet formations (Figs. 2, 3), with a regionally extensive SU at the base of the Helvetiafjellet Formation (Parker 1967; Steel \& Worsley 1984; Midtkandal \& Nystuen 2009). This SU formed during the early Barremian (Grøsfjeld 1992; Mørk \& Smelror 2001) and was caused by a relative sea-level fall induced by tectonic uplift (Gjelberg \& Steel 1995; Maher 2001). The unconformity incises the underlying Rurikfjellet Formation with variable magnitudes and cuts down into either open marine shelf or nearshore deposits (Fig. 2). The nearshore deposits of the Rurikfjellet Formation have previously been inferred to represent shoreline accretion under forced regressive conditions (Gjelberg \& Steel 1995). Because of the lack of any forced regressive features such as sharpbased and detached shoreface units (Plint 1988; Plint \& Nummedal 2000), the same deposits have also been suggested to represent deposition under normal regressive conditions (Edwards 1976; Midtkandal et al. 2007).

The Helvetiafjellet Formation consists of coarsegrained fluvial deposits which grade upward into coastal plain and eventually shallow marine facies (Nemec 1992; Gjelberg \& Steel 1995; Midtkandal et al. 2007; Fig. 2), reflecting deposition during a long-term relative sea-level rise. However, the facies development within the fluvio-deltaic Helvetiafjellet Formation is much debated and this has resulted in

CONTACT Sten-Andreas Grundvåg sten-andreas.grundvag@uit.no @Department of Geosciences, University of Troms $\varnothing-T h e$ Arctic University of Norway, PO Box 6050, NO-9037 Tromsø, Norway

(4) Supplemental data for this article can be accessed here. 


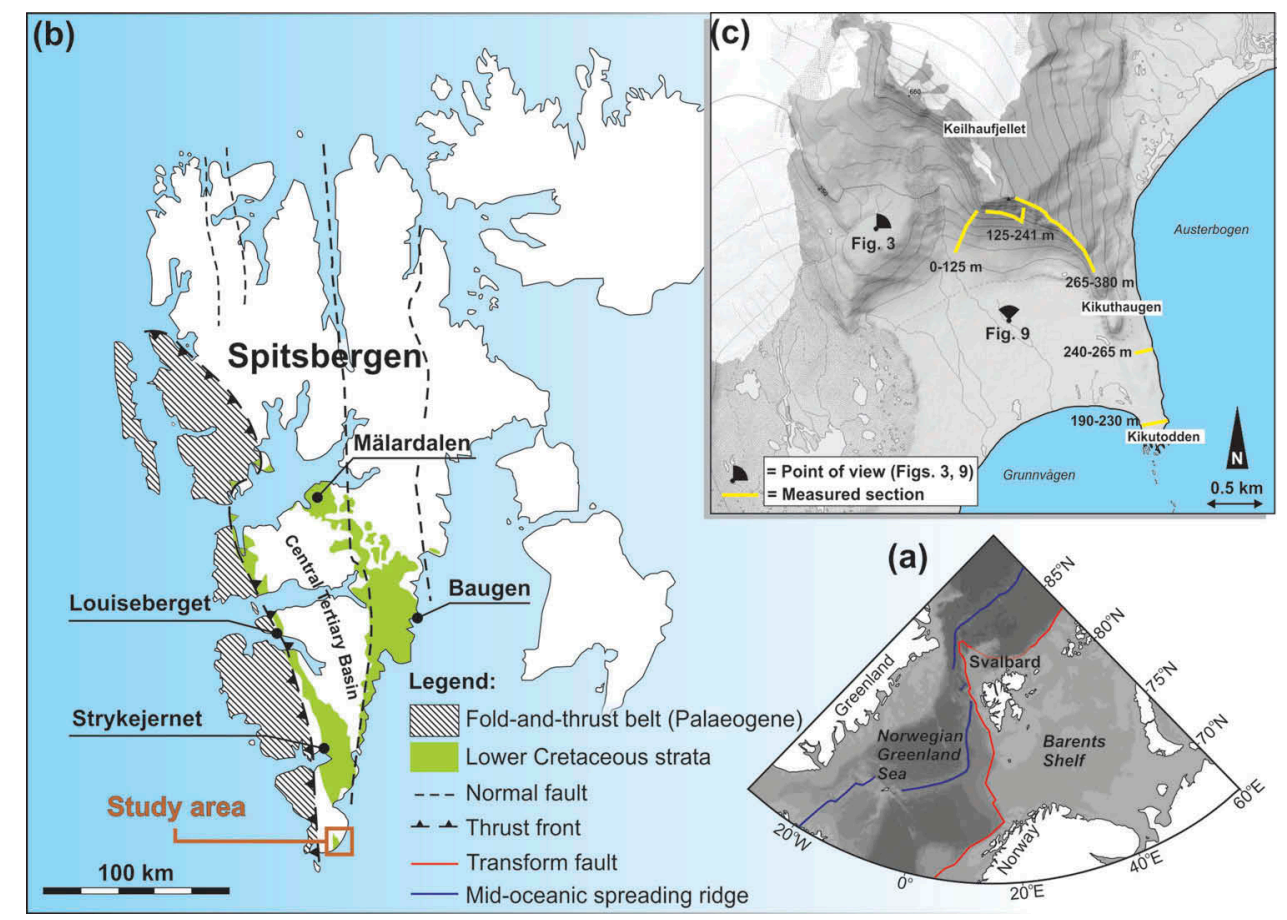

Figure 1. (a) Location map of Svalbard, in which the red line indicates the transform Hornsund Fault Zone and its southern extension, the Senja Fracture Zone, and the blue line represents mid-oceanic spreading ridges between Greenland and Svalbard. (b) Map of Spitsbergen showing the West Spitsbergen Fold-and-Thrust Belt and the Central Tertiary Basin. The green colour indicates distribution of the Lower Cretaceous (flanking the Central Tertiary Basin). Location of the study area (southern tip of Sørkapp Land) is highlighted, and place names mentioned in the text are annotated. (c) Map of the study area at Keilhaufjellet and Kikutodden. Yellow lines represent the measured sections used to create the composite log shown in Fig. 7. The stratigraphic position for each section in the composite log is also shown. The map is modified from TopoSvalbard (http://toposvalbard.npolar.no).

suggestions of various depositional models (Fig. 4; Nagy 1970; Nemec 1992; Gjelberg \& Steel 1995; Midtkandal \& Nystuen 2009). The first models suggested that the continental and paralic sediments were deposited as a synchronous system with a sheet-like geometry (layer-cake, see Parker 1967; Nagy 1970) and did not put forward any assumptions on how the system developed outside the outcrop window (Fig. 4). The original models were later replaced by a more complex regressive-transgressive model (Steel \& Worsley 1984; Nemec et al. 1988; Nemec 1992; Fig. 4), which stratigraphically linked the Rurikfjellet and Helvetiafjellet formations by inferring a lateral down-dip transition between braided stream and mouth bar deposits and acknowledging an overall transgressive development (Fig. 4). The interpretation that by far has received most attention is the overall transgressive diachronous model suggested by Gjelberg \& Steel (1995), which is basically a refined version of the regressive-transgressive model of Nemec (1992). However, the model by Gjelberg \& Steel (1995) displays a much clearer back-stepping trend with delta lobes pinching out within the outcrop window of Spitsbergen (Fig. 4) and infers a shoreline, or possibly a shelf-break (see Steel et al. 2000), with a maximum regression point just south of the present day outcrop window. The shelf-break model suggested by Steel et al. (2000) also predicts thick, sandy basin-floor fans offshore. In contrast, Midtkandal \& Nystuen (2009) have argued for a sheet-like architecture similar to the old layercake model (see Parker 1967; Nagy 1970). In their model, facies belts are mostly aggrading within the outcrop window, with back-stepping possibly occurring on a much larger scale (Fig. 4). In comparison with some of the older models (e.g., Gjelberg \& Steel 1995), the model of Mitkandal \& Nystuen (2009) implies a regressive-transgressive turn-around point somewhere to the south on the Barents Shelf (Fig. 4).

As a result of the various models (Fig. 4), the SU is either described as a single erosional surface that can be traced all across Svalbard (Parker 1967; Nagy 1970; Midtkandal et al. 2008; Midtkandal \& Nystuen 2009) or a series of interfingering diachronous unconformities (Gjelberg \& Steel 1995, 2012). The diachronous model indicates that the regressive-transgressive turnaround in the system took place just south-east of the present-day shoreline in Spitsbergen and that a shelf edge possibly developed in the same area (Steel et al. 2000; Fig. 4). In southern Spitsbergen, the magnitude of erosion has been suggested to be minimal because fluvial sandstones of the Helvetiafjellet Formation apparently overlie a thick succession of delta front and regressive lagoonal deposits (Edwards 1976; Mørk 1978). In contrast, the model of Midtkandal \& Nystuen (2009; Fig. 4) suggests that the SU acted 


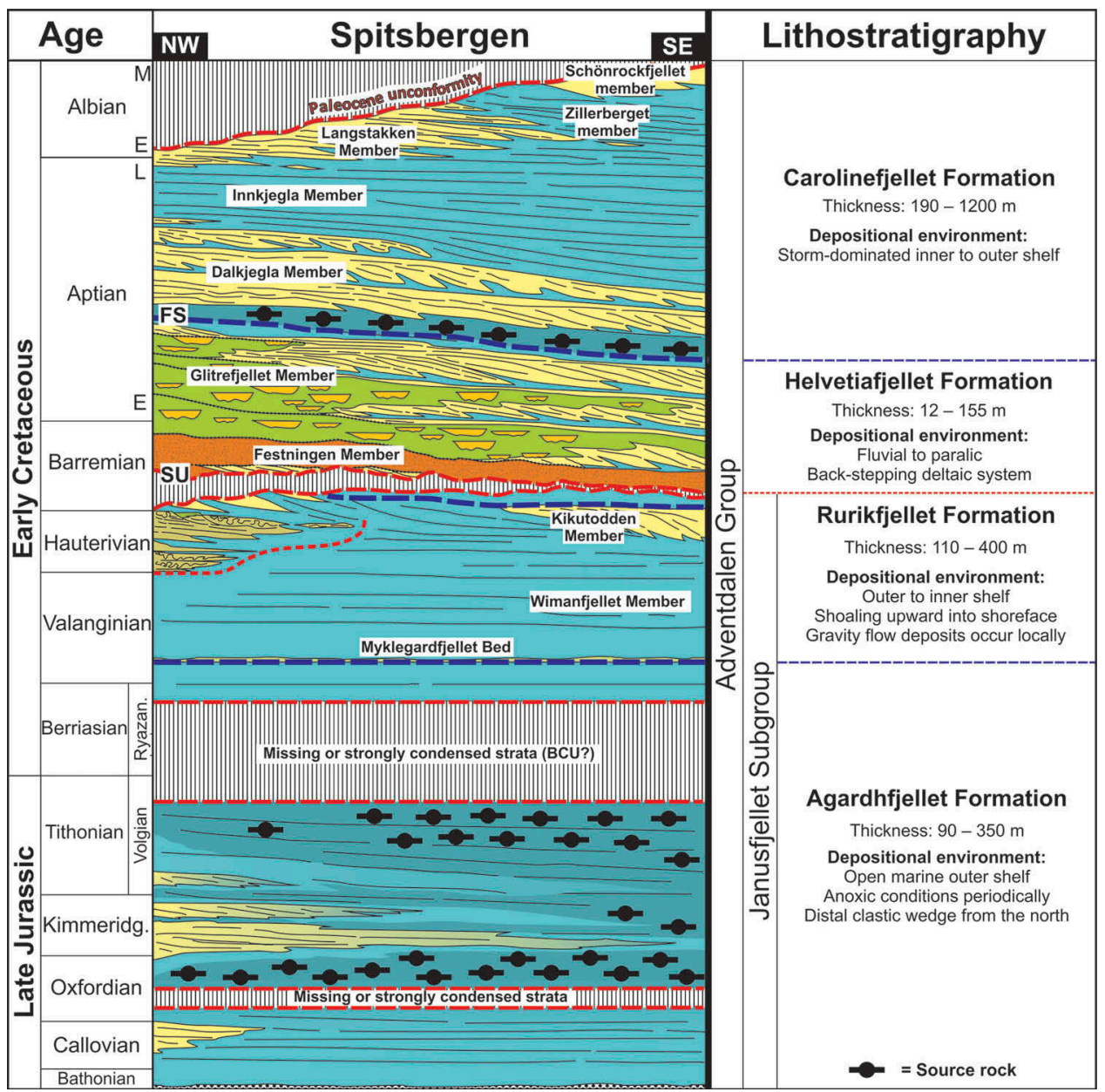

Figure 2. Stratigraphic cross-section of Spitsbergen from north-west to south-east showing the regional development of the Late Jurassic to Early Cretaceous Adventdalen Group. This study focuses on the Lower Cretaceous succession. Sch: Schönrockfjellet member; BCU: Base Cretaceous Unconformity; SU: Lower Barremian Subaerial Unconformity; FS: Lower Aptian Flooding Surface. The cross-section is compiled from Parker (1967), Nagy (1970), Steel \& Worsley (1984), Dypvik et al. (1991), Gjelberg \& Steel (1995), Midtkandal et al. (2008) and Hammer et al. (2011).

mainly as a bypass surface that promoted transport of fluvial sediments far out on the shelf because of the low-gradient ramp. This implies that the forced regression was non-accretionary in the Svalbard domain.

The aim of this paper is to demonstrate that parts of the disputed strata - the Rurikfjellet and Helvetiafjellet formations - in southern Spitsbergen show features typical of forced regression. For the first time in southern Spitsbergen sharp-based shallow marine deposits are documented in the uppermost part of the Rurikfjellet Formation just beneath the lower Barremian SU (Fig. 2). In order to provide a stratigraphic context, aspects of the surrounding deposits, particularly the depositional evolution of the upper Helvetiafjellet and lower Carolinefjellet formations (Fig. 2), are also discussed. In comparison to previous studies (Edwards 1976), this paper provides a more detailed description and an updated interpretation of the Lower Cretaceous in southern Spitsbergen. Finally, the implications of the new observations presented herein are discussed in terms of sequence stratigraphy and the possible southward and offshore continuation of the Lower Cretaceous, shedding new light on the link between onshore strata and the offshore subsurface.

\section{Geological setting}

\section{Tectonic framework}

Svalbard was located between $63^{\circ}$ and $66^{\circ} \mathrm{N}$ during the Early Cretaceous (Steel \& Worsley 1984; Torsvik et al. 2002) and was part of an extensive platform that was partly covered by a shallow epicontinental sea (Fig. 5). Svalbard also formed part of a larger landmass that was probably connected to the Lomonosov High and north-east Greenland (Fig. 5; Torsvik et al. 2002; Grantz et al. 2011). The depositional evolution of the Lower Cretaceous succession in Svalbard and adjacent areas was strongly influenced by thermotectonic activity associated with the opening of the Canada Basin in Hauterivian to Barremian times (Maher 2001; Lawver et al. 2002; Golonka et al. 2003; Grantz et al. 2011; Fig. 5). Thermal doming and epeirogenic differential uplift of the Lomonosov High and the northern Barents Shelf (Ziegler 1988; 

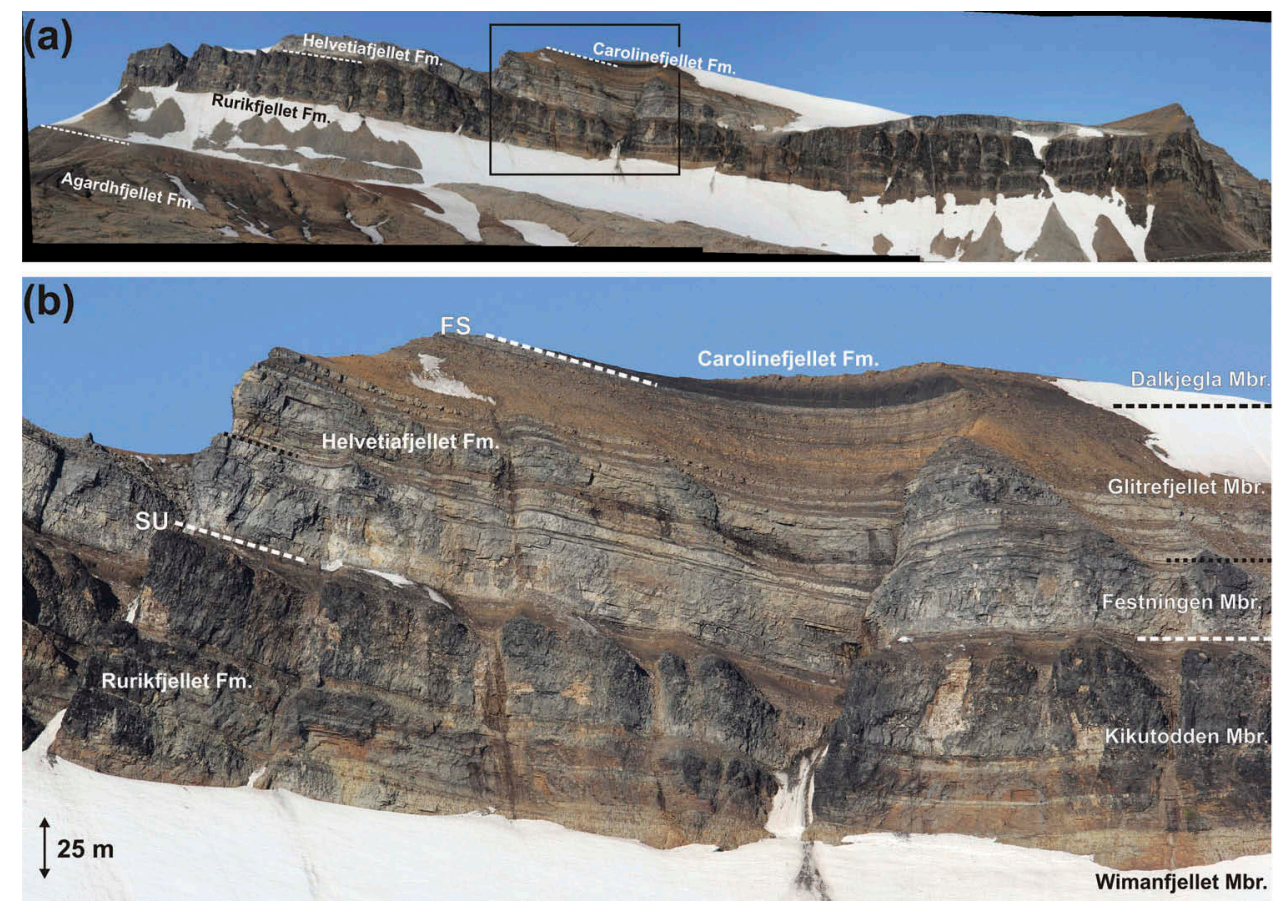

Figure 3. (a) Overview of the west face of Keilhaufjellet (Fig. 1 for location), showing the stratigraphic development of the Lower Cretaceous in the study area. The black square denotes position of the close-up shown in (b). The lithostratigraphic units are easily recognizable. Note the sandy, coarse-grained development of the Kikutodden Member in the upper part of the Rurikfjellet Formation and the subaerial unconformity (SU) at the base of the Helvetiafjellet Formation. Note also the dark shale that separates the Helvetiafjellet and Carolinefjellet formations recording a regional, early Aptian flooding surface (FS).

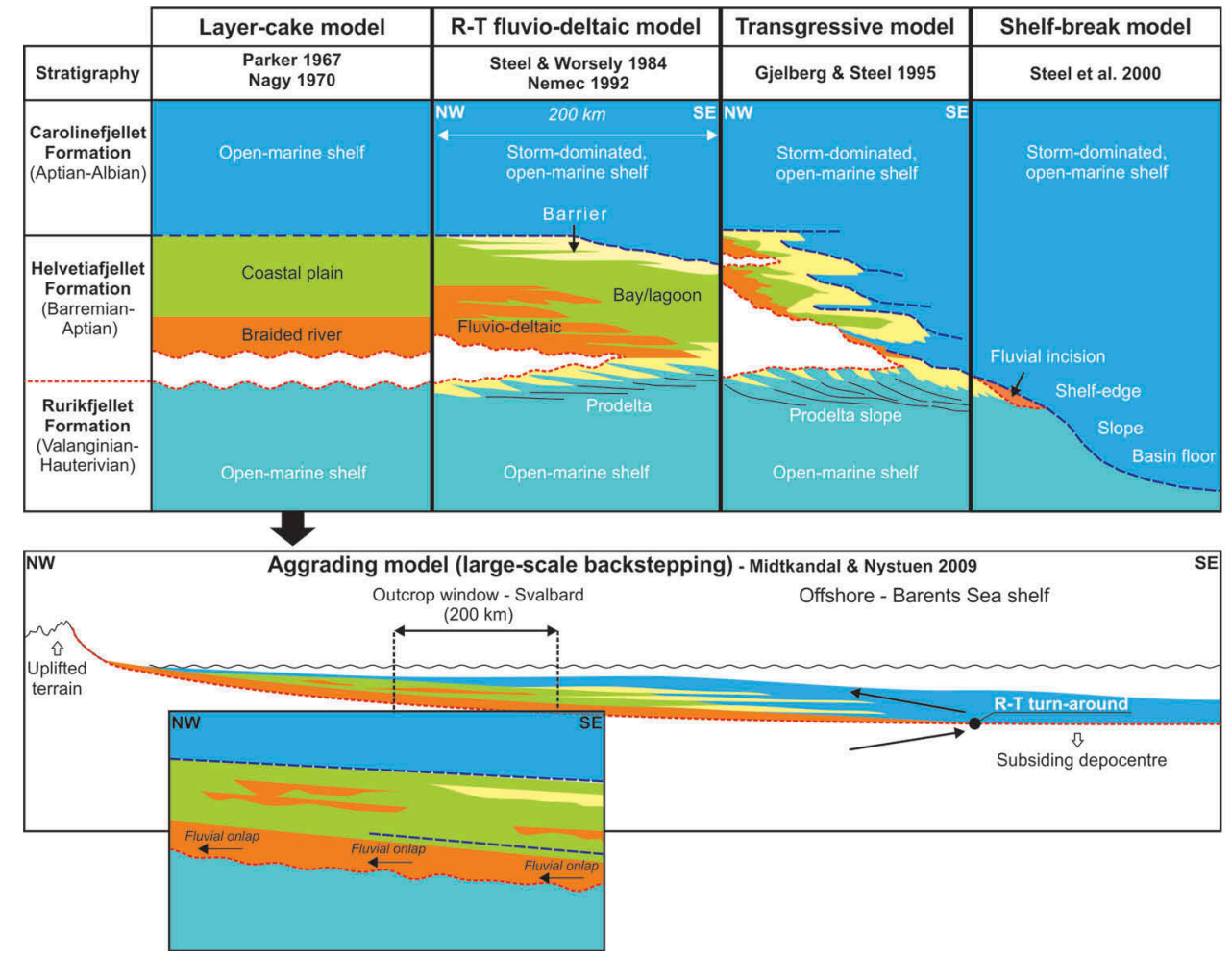

Figure 4. A summary of previous stratigraphic models for the Lower Cretaceous succession in Spitsbergen. Modified from Nemec et al. (1988), Nemec (1992), Gjelberg \& Steel (1995), Steel et al. (2000) and Midtkandal \& Nystuen (2009). See the main text for more details on each model.

Fig. 5) during the early Barremian resulted in the formation of a regionally extensive SU (Fig. 2). In Svalbard, the SU is recorded at the base of the Helvetiafjellet Formation (Figs. 2, 3; Parker 1967;
Midtkandal et al. 2008). Furthermore, a younger, regionally extensive hiatus separates the Lower Cretaceous from the Palaeogene strata (Nagy 1970; Fig. 2). This Late Cretaceous hiatus, with increasing 


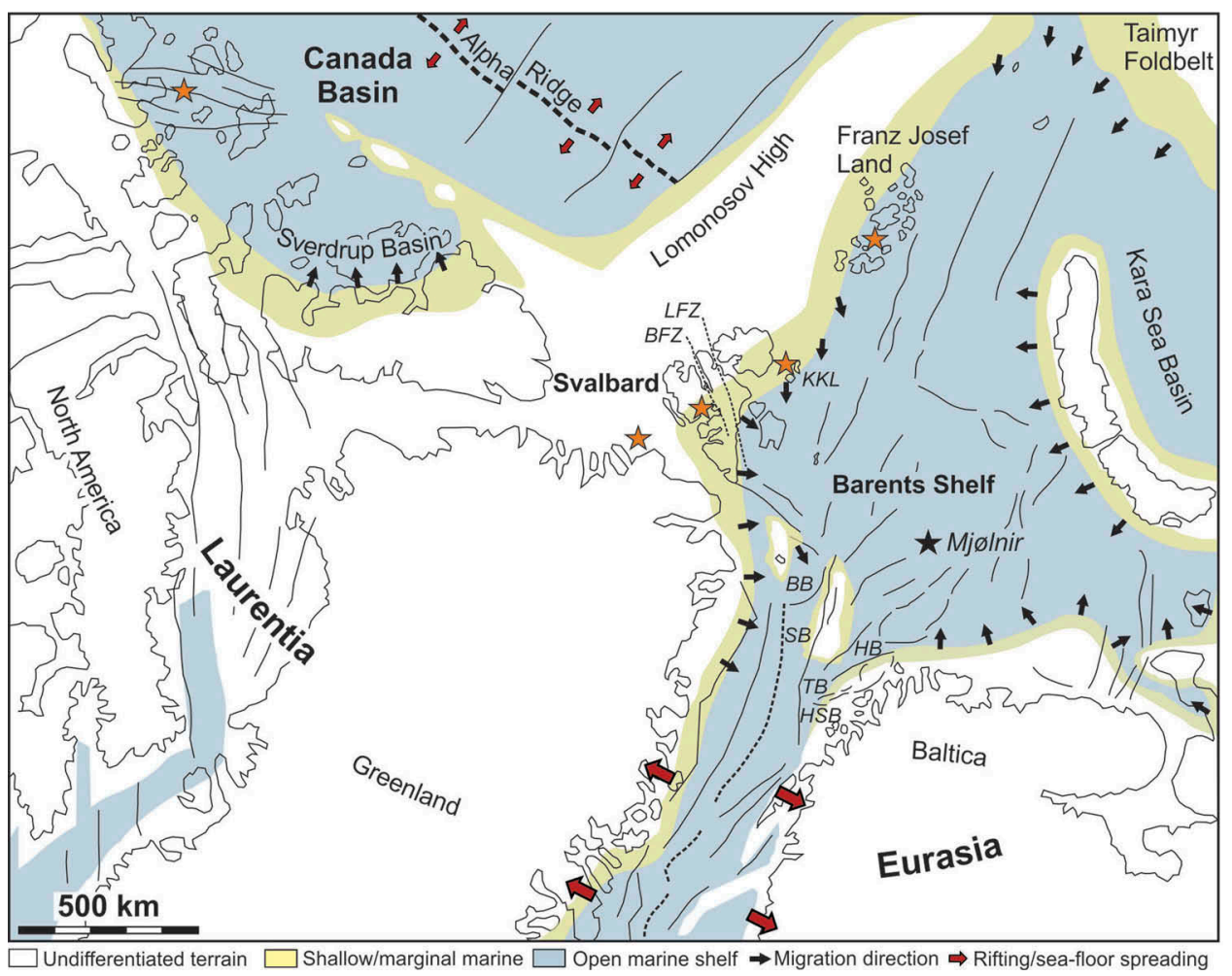

Figure 5. Palaeogeographic reconstruction showing the location of Svalbard during the Early Cretaceous (HauterivianBarremian). The map is based on Steel \& Worsley (1984), Ziegler (1988), Torsvik et al. (2002) and this study. Stars indicate areas where igneous activity has been recorded. Black arrows indicate prograding shoreline systems. BFZ: Billefjorden Fault Zone; LFZ: Lomfjorden Fault Zone; BB: Bjørnøya Basin; HB: Hammerfest Basin; HSB: Harstad Basin; SB: Sørvestsnaget Basin; TB: Tromsø Basin; KKL: Kong Karls Land.

erosional relief northwards (Nagy 1970), is also attributed to uplift of the northern margin of the Barents Shelf (Maher 2001).

Only minor tectonic activity has been reported from the Mesozoic succession in Svalbard and nearby offshore areas (Nemec et al. 1988; Gjelberg \& Steel 1995; Anell et al. 2013). Deposition took place mostly in epicontinental sag basins on a tectonically stable platform that in the Early Cretaceous was characterized by uplift in the north and increasingly higher rates of subsidence to the south (Steel \& Worsley 1984). The southward tilting forced the Lower Cretaceous system to prograde to the south (Steel \& Worsley 1984; Gjelberg \& Steel 1995). New basins started to form during Late Cretaceous and Paleocene times as a result of major transform faulting linked to seafloor spreading in the North Atlantic Ocean (Faleide et al. 1993). Transpressional tectonics in the Palaeogene formed the West Spitsbergen Foldand-Thrust Belt and an accompanying foreland basin: the Central Tertiary Basin (Bergh et al. 1997; Braathen et al. 1999; Fig. 1). Subsequent transtension in the Neogene established a renewed link between the North Atlantic and the Polar basins (Faleide et al. 2008). On the basis of vitrinite reflectance analysis (Manum \& Throndsen 1978), and in light of the present day thermal gradient, it has been inferred that at least $1000 \mathrm{~m}$ of additional sediments were deposited on top of the preserved part of the Central Tertiary Basin and later eroded in Late Cenozoic times with erosion increasing towards the south (Paech \& Koch 2001). Uplift in the order of more than $3 \mathrm{~km}$ has previously been postulated for the Central Tertiary Basin (Throndsen 1982). However, Marshall et al. (2015) estimated a higher palaeo-temperature gradient than previous studies and suggested an uplift of ca. $2 \mathrm{~km}$. Therefore, deep burial with temperatures elevated to more than $120^{\circ} \mathrm{C}$ $\left(50^{\circ} \mathrm{C} \mathrm{km}^{-1}\right.$, Marshall et al. 2015) and proximity to the transform Hornsund Fault Zone (Faleide et al. 2008; Fig. 1) have diagenetically altered the Lower Cretaceous sandstones in Sørkapp Land to mainly tight quartz-cemented sandstones (Edwards 1978). Siderite- and calcite-cemented sandstones occur at a lesser extent. However, sedimentary and biogenic structures are generally well preserved.

Igneous activity related to opening of the Canada Basin resulted in circum-Arctic igneous activity, creating HALIP (Maher 2001; Senger et al. 2014). In Svalbard, the HALIP is evident through dolerite intrusions, bentonites, as well as basalt flows on Kong Karls Land (Tyrrell \& Sandford 1933; Smith et al. 1976; Grogan et al. 1998; Senger et al. 2014). The presence of a volcanic source terrain north and east of Svalbard is also evident from the high content of volcanic 
minerals in the upper Helvetiafjellet Formation and throughout the overlying Carolinefjellet Formation (Edwards 1978; Maher 2001; Maher et al. 2004).

\section{Early Cretaceous climate}

Despite its relatively high palaeo-latitude during the Early Cretaceous $\left(63-66^{\circ} \mathrm{N}\right)$, Svalbard had a generally warm-temperate (mean annual temperature of $7-10^{\circ} \mathrm{C}$ ) and humid climate that supported an ornithopod dinosaur population, deciduous conifers, ginkgos and peat accumulations developing into relatively thick coal seams (Steel \& Worsley 1984; Nemec 1992; Harland et al. 2007; Hurum et al. 2016). The warm climate was related to global greenhouse conditions, with the Cretaceous being one of the warmest periods in Earth's history (Hallam 1985). The greenhouse climate prevented formation of major permanent ice caps in the polar regions (Hallam 1985; Price 1999), which gave rise to a historically high eustatic sea level (Markwick \& Rowley 1998; Miller et al. 2005). A warm or at least seasonally warm humid climate is also supported by the common occurrence of kaolinite as both pore filling mineral and in distinct beds that may be associated with soil forming processes (e.g., Sheldon \& Tabor 2009). Glendonites (i.e., calcite pseudomorphs of ikaite, a metastable and hydrated form of calcium carbonate; Suess et al. 1982), possible ice-rafted debris and a mixture of non-endemic, cold-water dinoflagellates in finegrained shelf strata occur at several stratigraphic intervals (i.e., in the Rurikfjellet and Carolinefjellet formations). This suggests that cold polar water periodically invaded the shelf, possibly via a narrow seaway west of Svalbard (Århus 1991; Mutterlose \& Kessels 2000; Selleck et al. 2007; Price \& Nunn 2010). The pulses of cold water may alternatively relate to short periods $(<3$ My) of global cooling which evidently occurred in the Berriasian, Valanginian and early Aptian (Royer 2006). Some studies have also suggested that short-lived ice caps periodically may have existed (Francis \& Frakes 1993; Ditchfield 1997). Together, the climatic proxies indicate that Svalbard experienced a general warm climate during the Early Cretaceous, although with some cooler pulses and possibly seasonal variations.

\section{Lithostratigraphy and depositional system}

Together, the Rurikfjellet, Helvetiafjellet and Carolinefjellet formations (Parker 1967; Figs 2, 3) form a more than $1700 \mathrm{~m}$ thick first-order regressive-transgressive sequence (Gjelberg \& Steel 1995; Figs. 2, 6). The Rurikfjellet Formation (ValanginianHauterivian/early Barremian) represents deposition in an open marine shelf environment (Wimanfjellet Member, Figs 2, 3; Dypvik et al. 1991), shoaling upward into nearshore environments (Kikutodden
Member; Figs. 2, 3, 6; Dypvik et al. 1991; Midtkandal et al. 2008). The overlying Helvetiafjellet Formation (early Barremian-early Aptian) represents a fluvio-deltaic system that was deposited during a long-term relative sea-level rise (Gjelberg \& Steel 1995; Midtkandal \& Nystuen 2009; Figs. 2, 3, 6). Although the formation is characterized by an overall transgressive development, it contains several higherfrequency regressive-transgressive cycles that give rise to a large-scale retrogradational architecture (Nemec et al. 1988; Gjelberg \& Steel 1995; Fig. 2). The lower Festningen Member (Parker 1967; Midtkandal et al. 2008) represents a braided river system that accumulated during early stages of relative sea-level rise. The base of the unit is defined by the regional lower Barremian SU (Nemec 1992; Gjelberg \& Steel 1995; Midtkandal et al. 2007; Figs 2, 3, 6). The Glitrefjellet Member (Parker 1967; Steel et al. 1978; Midtkandal et al. 2008; Fig. 2) is more heterolithic and consists of various paralic deposits. The Carolinefjellet Formation (Aptian-middle Albian) may represent the distal storm-reworked shelf segment of the underlying and laterally equivalent fluvio-deltaic Helvetiafjellet Formation (Gjelberg \& Steel 1995; Mutrux et al. 2008; Figs. 2, 6). Because of repeated uplift and erosion in the Late Cretaceous and Cenozoic, no Upper Cretaceous strata are preserved in Svalbard. However, reworked Maastrichtian palynomorphs occur in the Paleocene of Spitsbergen (Smelror \& Larssen 2016). On the basis of sedimentation rates in the Aptian and Albian, it is estimated that at least $1000 \mathrm{~m}$ of Upper Cretaceous strata were deposited and later eroded (Michelsen \& Khorasani 1991). The eroded Upper Cretaceous sediments was probably transported and deposited in the deeper basins to the south of Svalbard (e.g., the Sørvestsnaget Basin; Ryseth et al. 2003).

\section{Data set and methods}

The study area is located in Sørkapp Land on the southern tip of Spitsbergen (Fig. 1b). The Lower Cretaceous is exposed in a continuous cliff along the steep west face of Keilhaufjellet (Figs. 1c, 3) and along coastal sections at Kikutodden (Fig. 1c). Palaeogene compressional tectonics caused the outcrop belt to dip at a low angle (some few degrees) toward the eastnorth-east. Several steep ravines that cut the vertical cliffs of Keilhaufjellet were climbed in order to access better exposures, resulting in a more continuous section than what has been published by other workers (Edwards 1976). The sedimentary logs were measured bed-by-bed at centimetre-scale and include descriptions of rock type, grain size, sorting, sedimentary structures, body and trace fossils and palaeo-current data. Degree of bioturbation follows the BI of Taylor and Goldring (1993). Lateral facies transitions, facies 

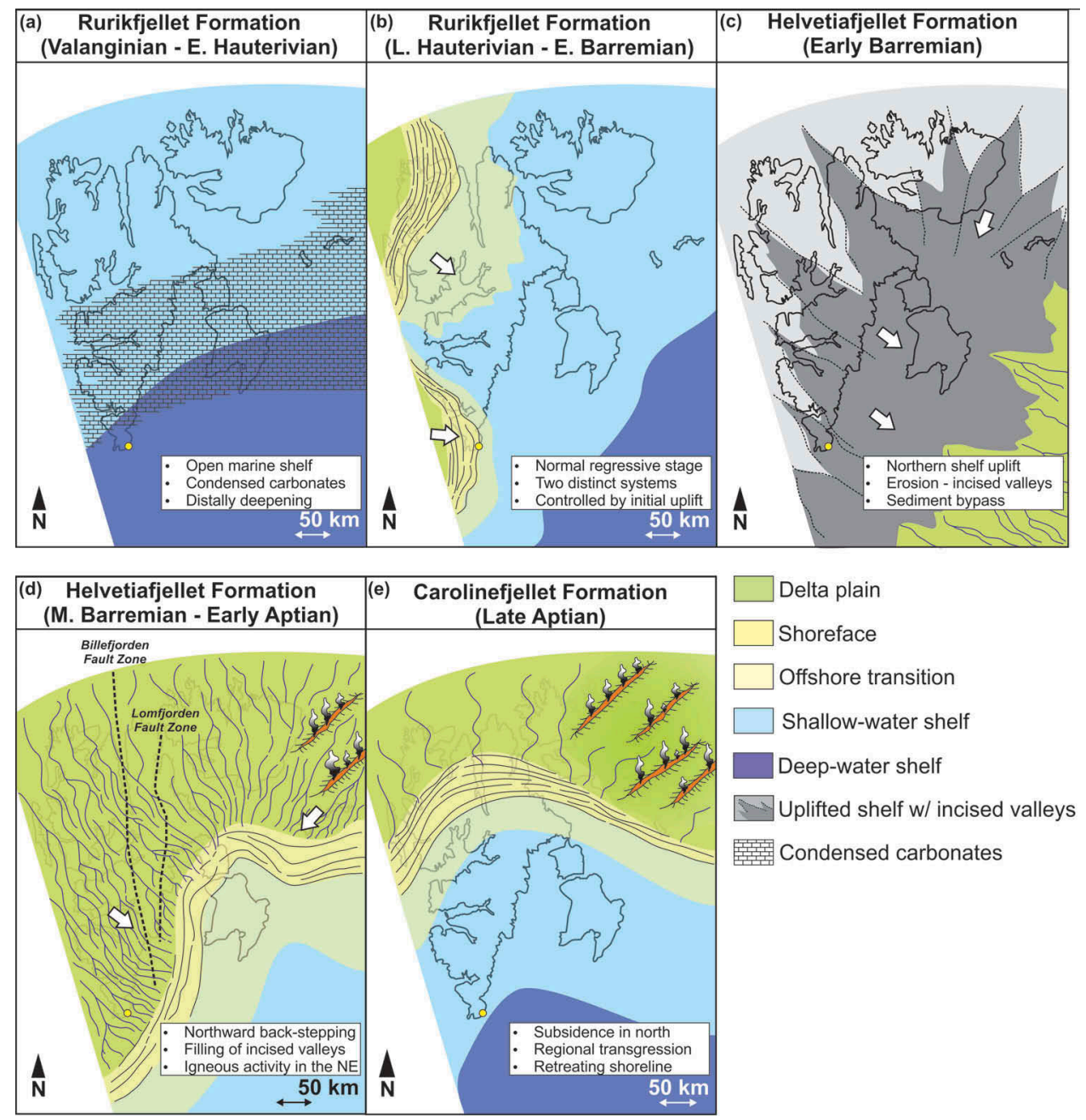

Figure 6. Generalized palaeogeographic reconstruction of Svalbard's shorelines during the Early Cretaceous. (a) ValanginianHauterivian, ca. 134 Mya; (b) late Hauterivian-early Barremian, ca. 131 Mya; (c) early Barremian, ca. 130 Mya; (d) middle Barremian-early Aptian, ca. 127-125 Mya; (e) late Aptian, ca. 115 Mya. Note that large parts of the shelf were uplifted and exposed in early Barremian, resulting in the formation of incised valleys. These valleys acted as conduits for eroded sediments, which was transported southward and deposited in the offshore (subsurface) basins on the Barents Shelf. Reconstructions based on Steel \& Worsley (1984), Worsley (1986), Dypvik et al. (1991), Midtkandal \& Nystuen (2009) and this study. Yellow circle indicate the study area in Sørkapp Land.

architecture, stratal geometries and major stratigraphic surfaces were determined visually by binoculars in the field and later by tracing on photo mosaics. The measured sections were combined into a composite section that covers the entire Rurikfjellet and Helvetiafjellet formations and the exposed part of the Carolinefjellet Formation (Fig. 7; see Fig. 1c for location and stratigraphic position of the various sections). Some samples were also collected for biostratigraphic analyses. However, because of the proximity to the fold-and-thrust belt and the increased thermal gradient during burial, none of the samples revealed any well-preserved age-diagnostic dinocysts.

\section{Facies associations}

From the analysis of outcrop data, 11 FAs are recognized (FA 1-11; Fig. 7; Table 1). FAs 1-4
(Supplementary Figs. S1, S2) grossly represent deposition in offshore shelf to nearshore environments and are restricted to the Rurikfjellet Formation. FA 5 (Fig. 8, Supplementary Fig. S3) occurs as a $<3 \mathrm{~m}$ thick unit in the uppermost Rurikfjellet Formation just beneath the SU at the base of the Helvetiafjellet Formation and represents deposition within an interpreted incised valley. Despite its modest thickness of FA 5, the unit is referred to a separate FA because of its unique sedimentary and ichnological characteristics. FA 6-10 (Supplementary Fig. S4) are restricted to the Helvetiafjellet Formation. FA 6 is attributed to deposition in a braid plain environment and only occurs in the lowermost Festningen Member. FAs 7-9 grossly represent deposition in a coastal/delta plain environment, whereas FA 10 represents a delta front setting, all occurring in the Glitrefjellet 

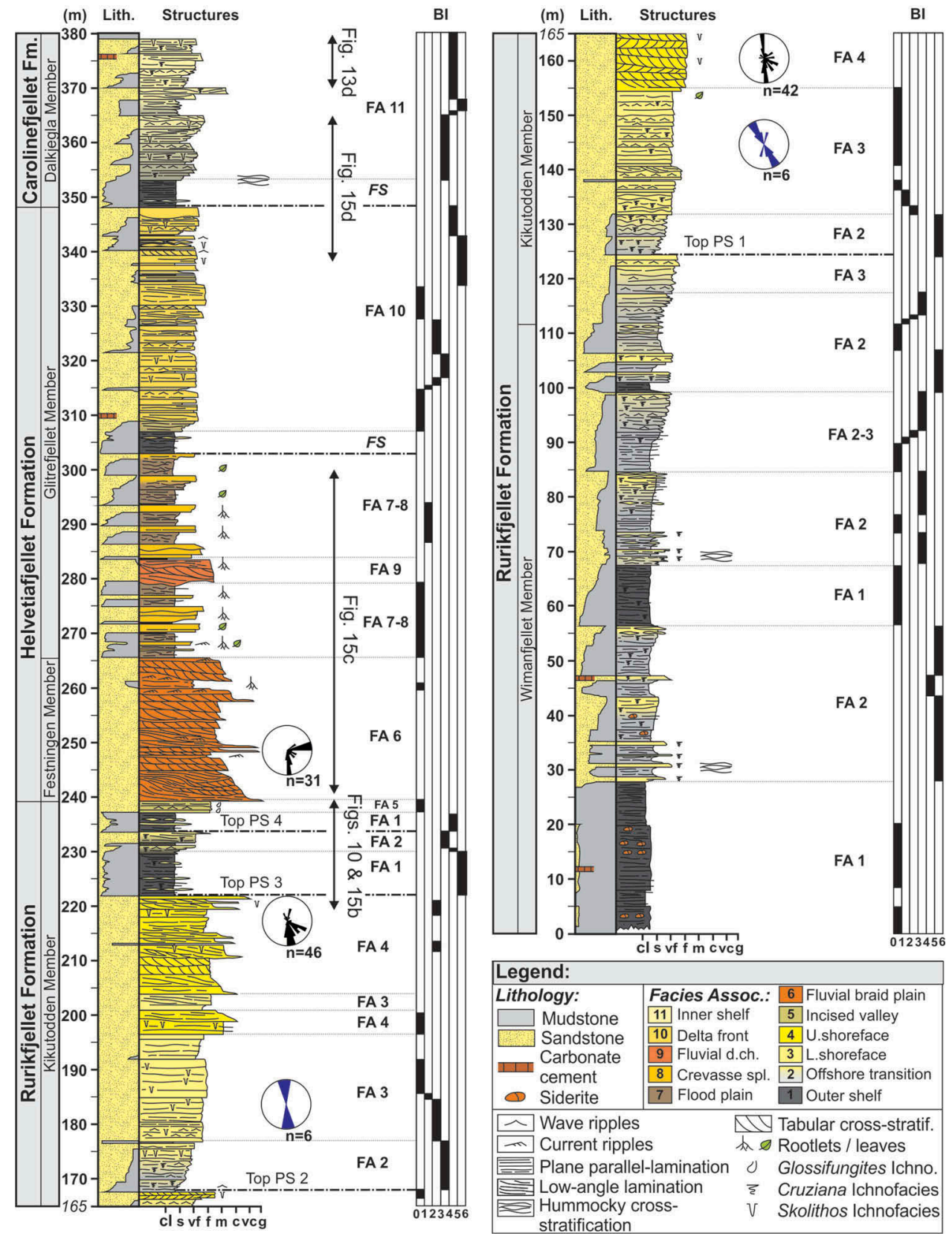

Fig. 7. Composite sedimentological log through the Lower Cretaceous at Keilhaufjellet and Kikutodden, Sørkapp Land. The log is summarized from several longer and shorter measured sections (see Fig. 1c for locations). Apart from sedimentary structures and lithologies, the log shows lithostratigraphic units, interpreted facies, palaeo-flow directions and BI.

Member. FA 11 (Supplementary Fig. S5) represents deposition in inner shelf to nearshore environments and occurs in the Carolinefjellet Formation. In terms of depositional environments, FA 11 is in part similar to the facies observed in both the Rurikfjellet Formation (FAs 2-3) and in the uppermost Helvetiafjellet Formation (FA 10). However, because of differences in stacking patterns, grainsize, sand-to-shale ratio and the dominance of storm-generated structures, FA 11 is regarded as an individual association. Key characteristics and interpretations of all the FAs are given in the supplementary material. A summary is found in Table 1.

\section{Stratigraphic arrangement and facies development}

The Rurikfjellet Formation consists of the lower shale-dominated Wimanfjellet Member and the overlying sandstone-dominated Kikutodden Member (Figs. 3, 7; Midtkandal et al. 2008). Together the two units record a long-term upward-shoaling from outer to inner shelf and nearshore environments. The offshore shelf FA (FA 1) is volumetrically the most important FA in the Rurikfjellet Formation and constitutes a several hundred metres thick shale succession in the Wimanfjellet Member (Fig. 7). The shales grade upwards into more sandstone-rich deposits of 


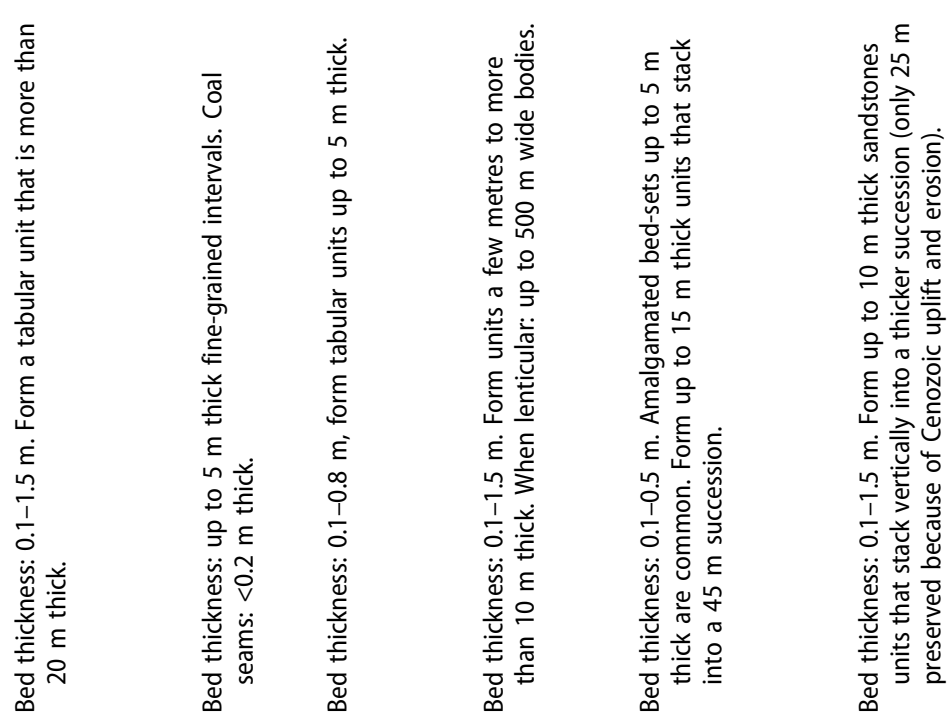

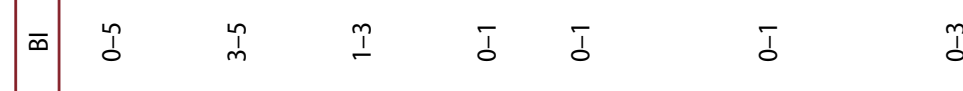

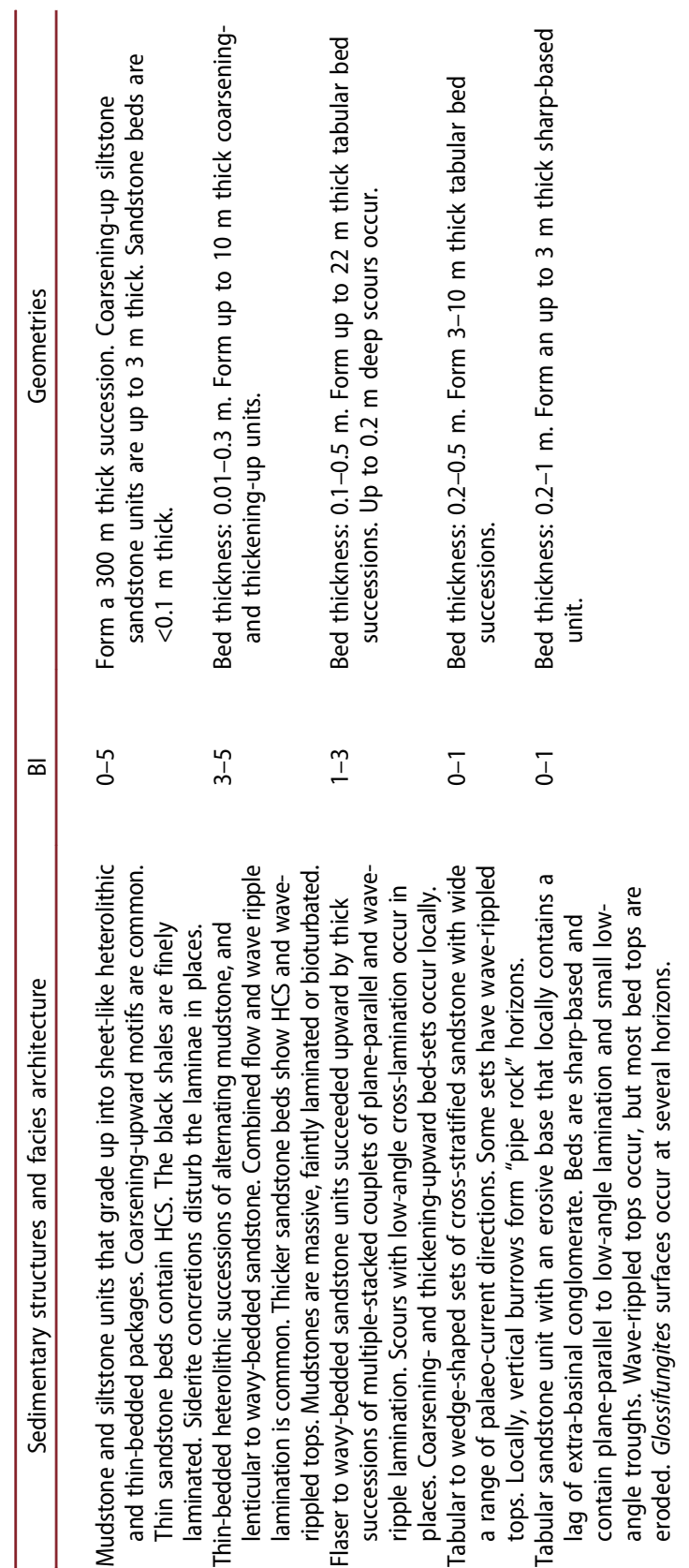

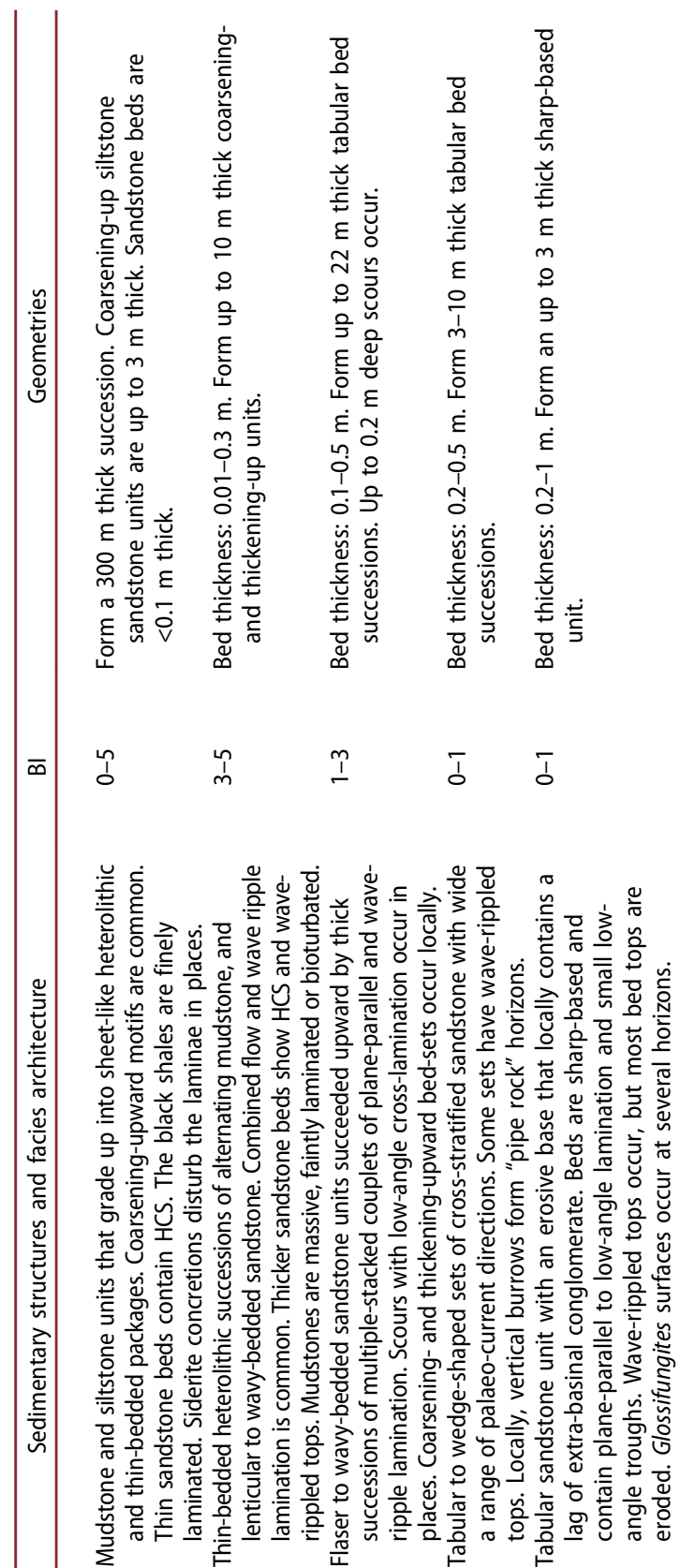

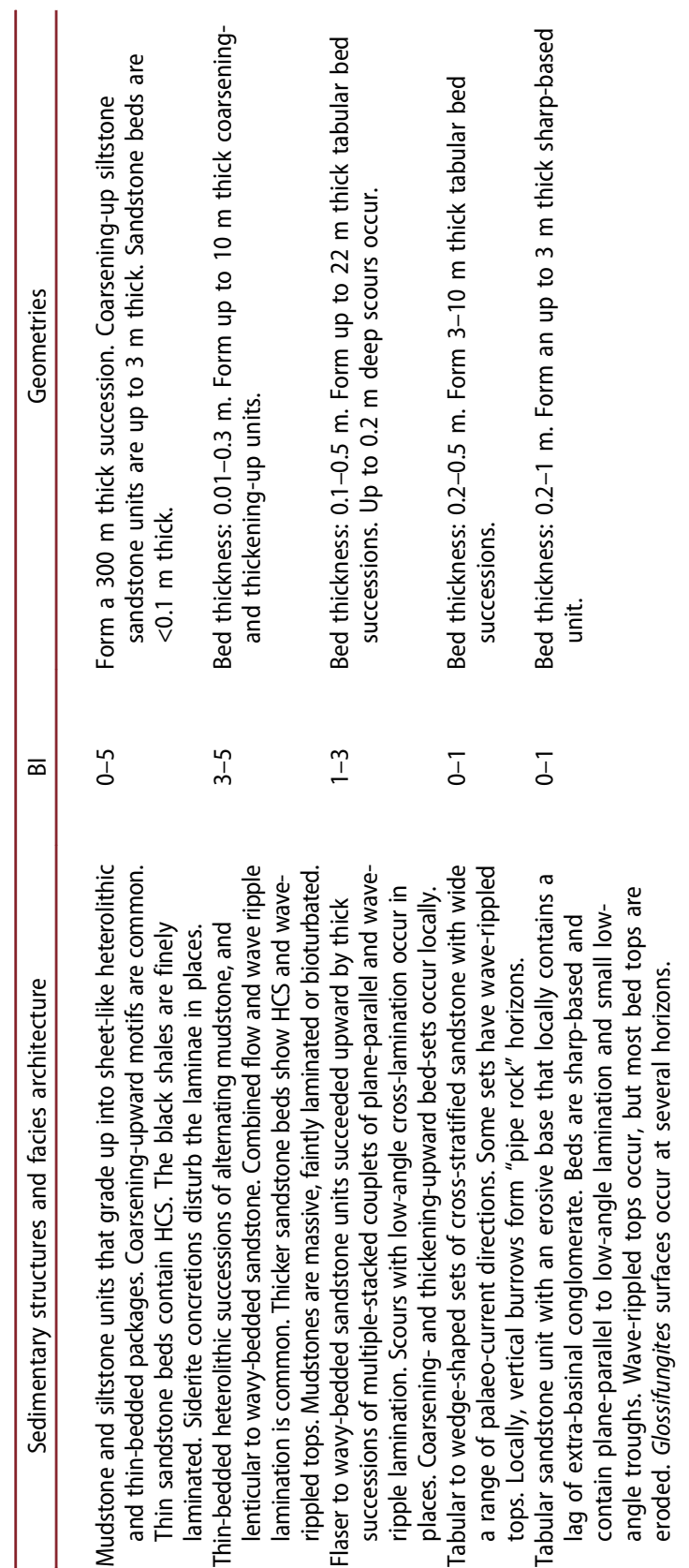

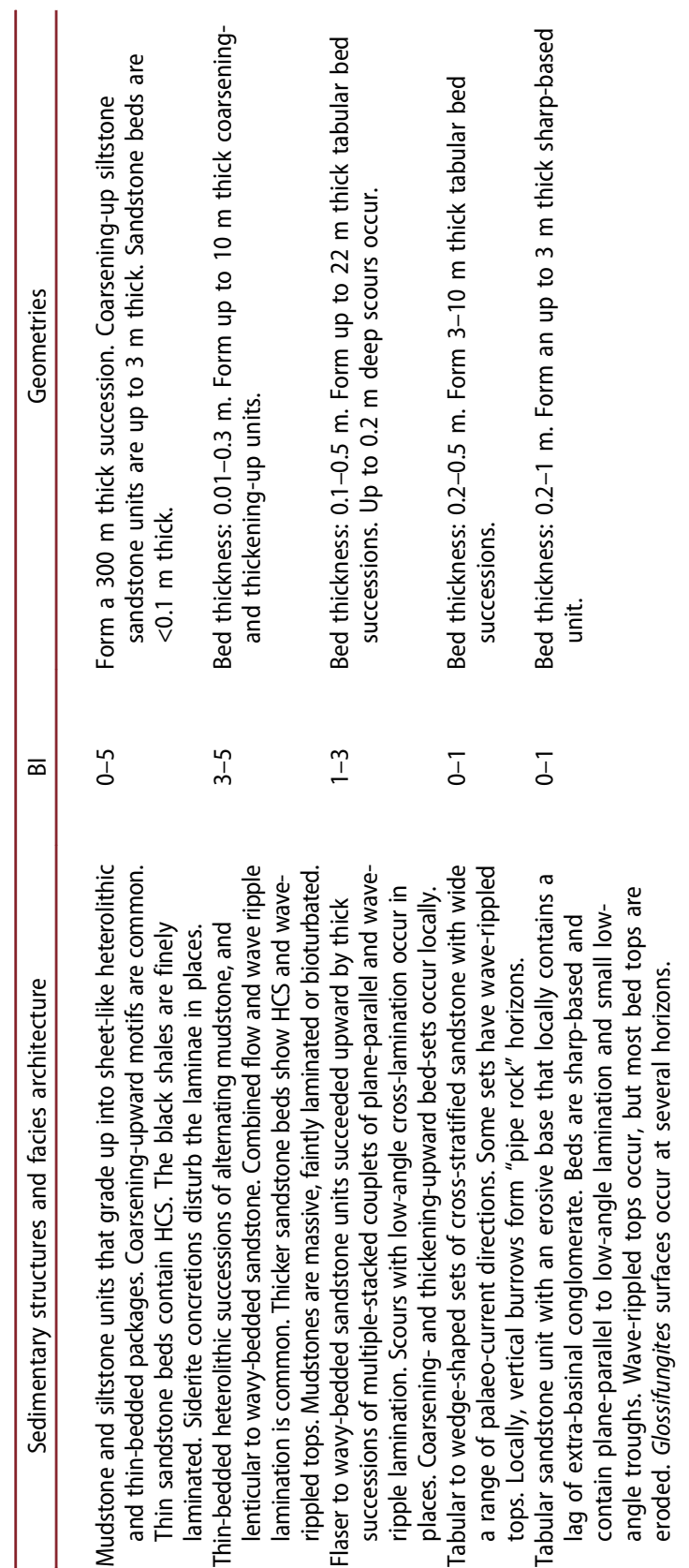

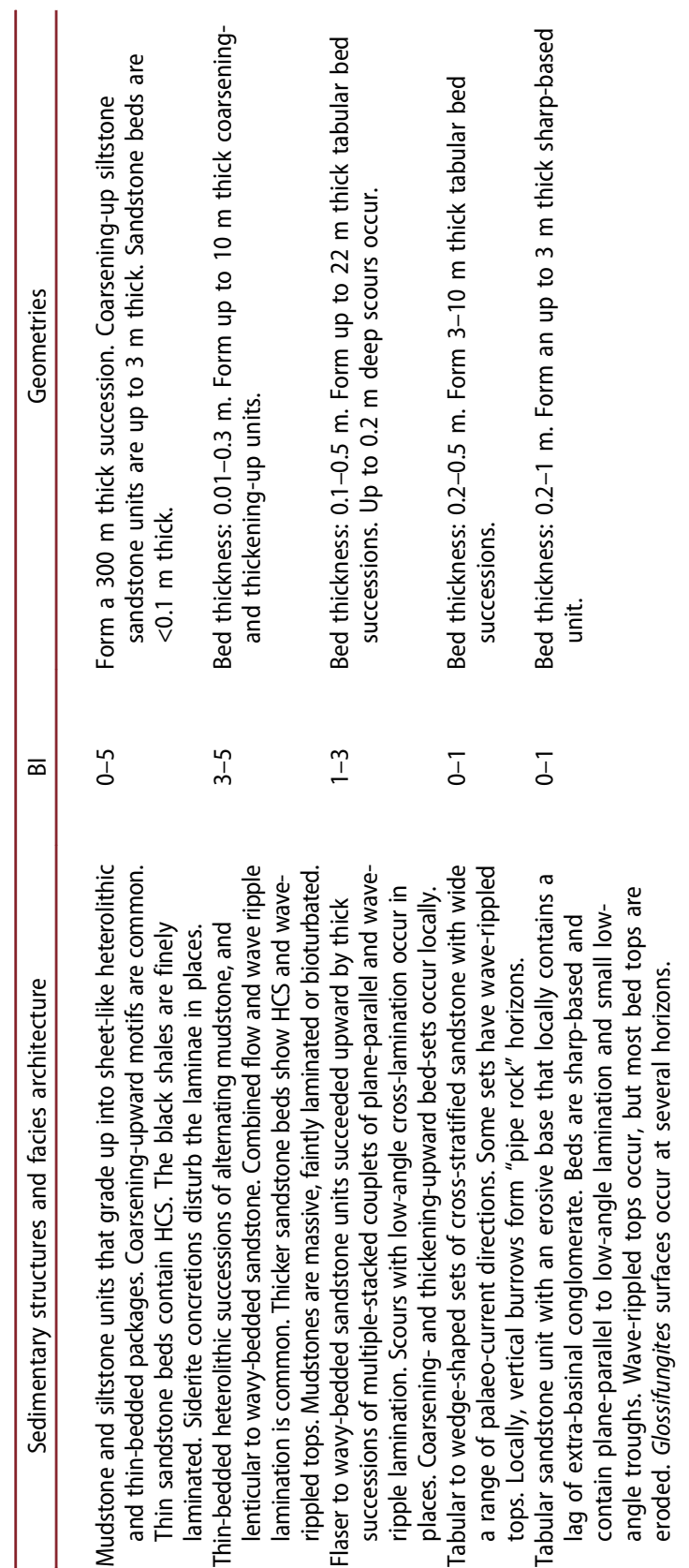

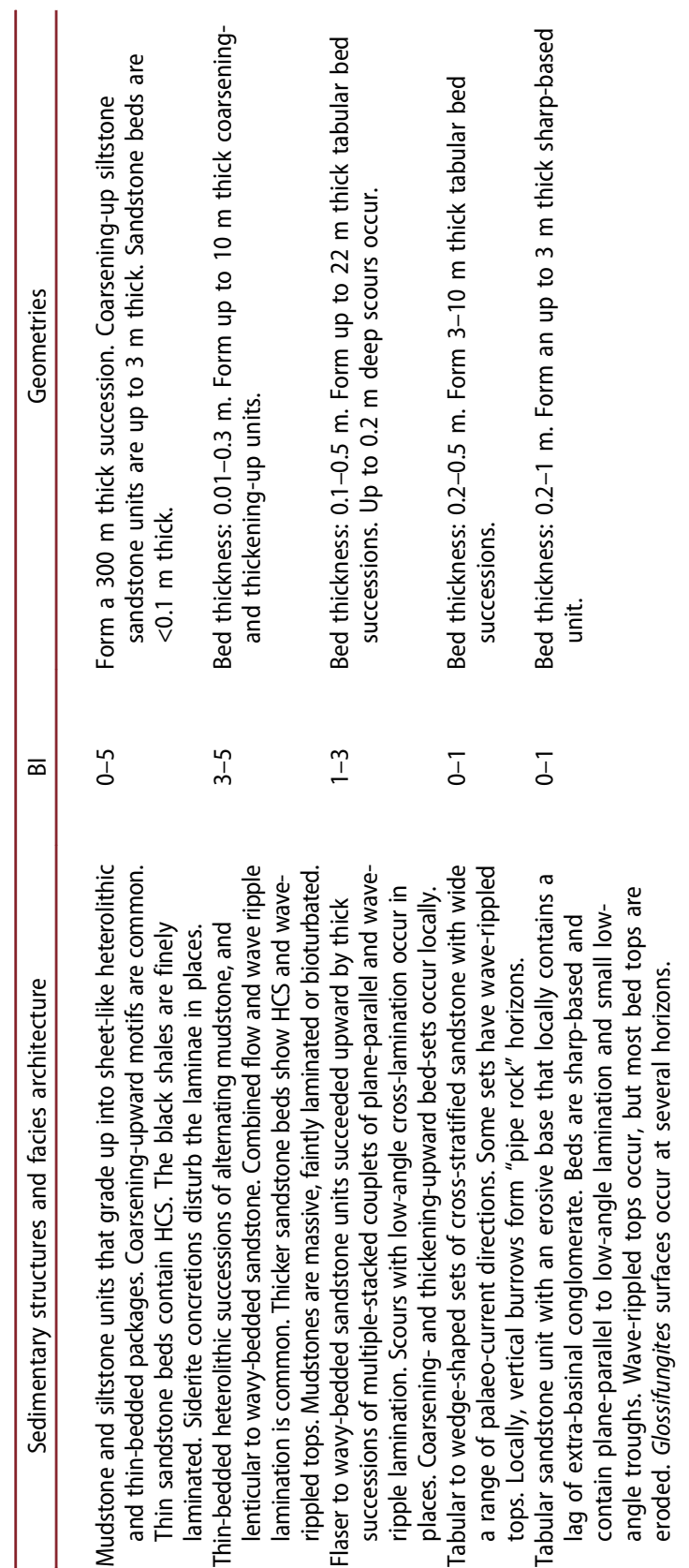

o

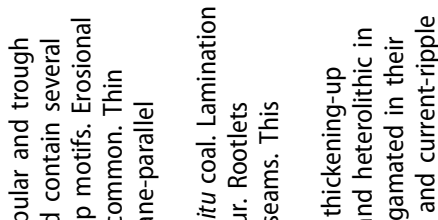

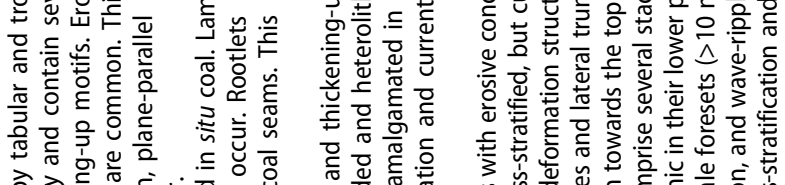

$\stackrel{\varphi}{\varphi}$

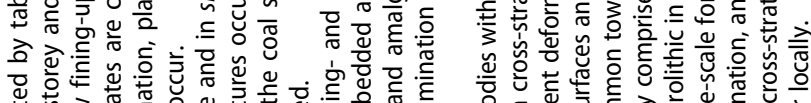

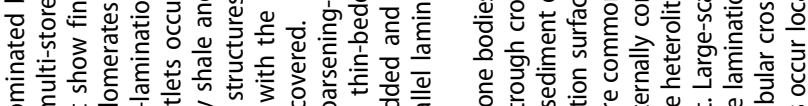

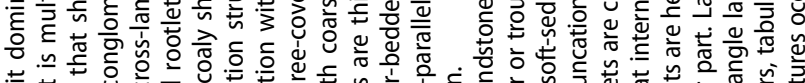

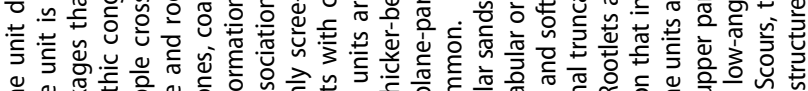

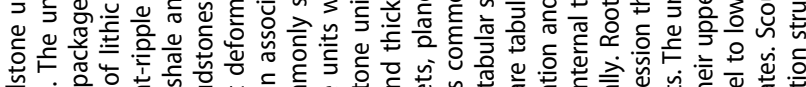

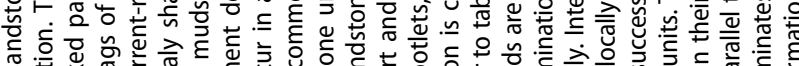

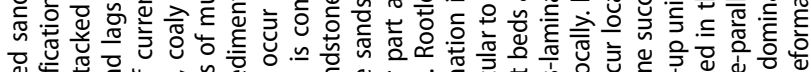

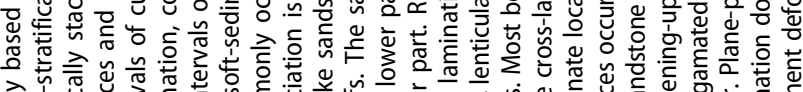

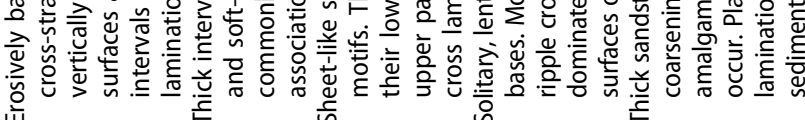

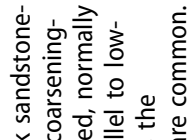

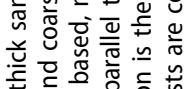

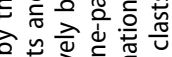

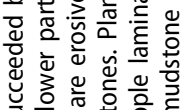

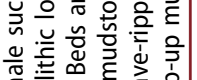
可 원.

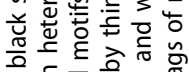

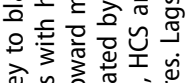

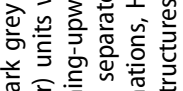

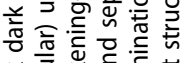

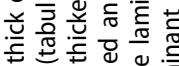
든든
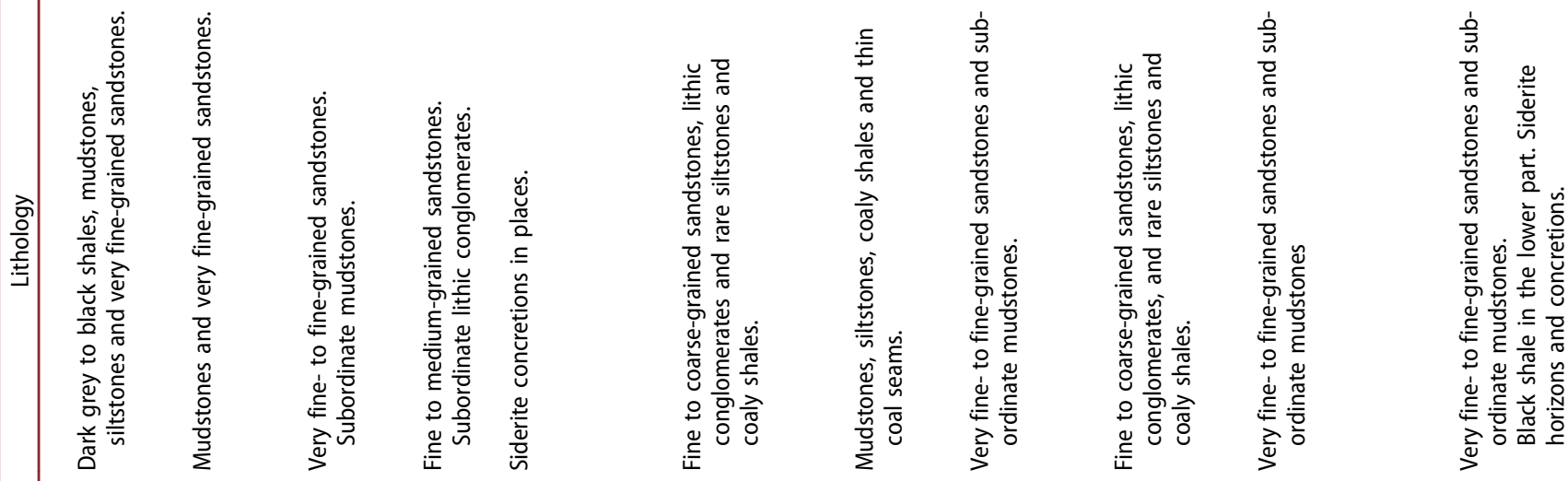

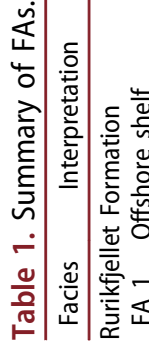

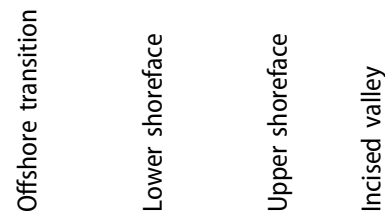

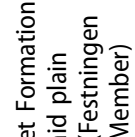

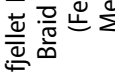

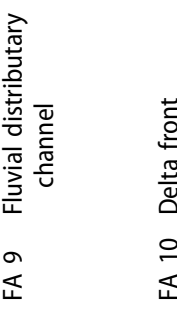

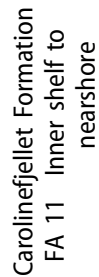




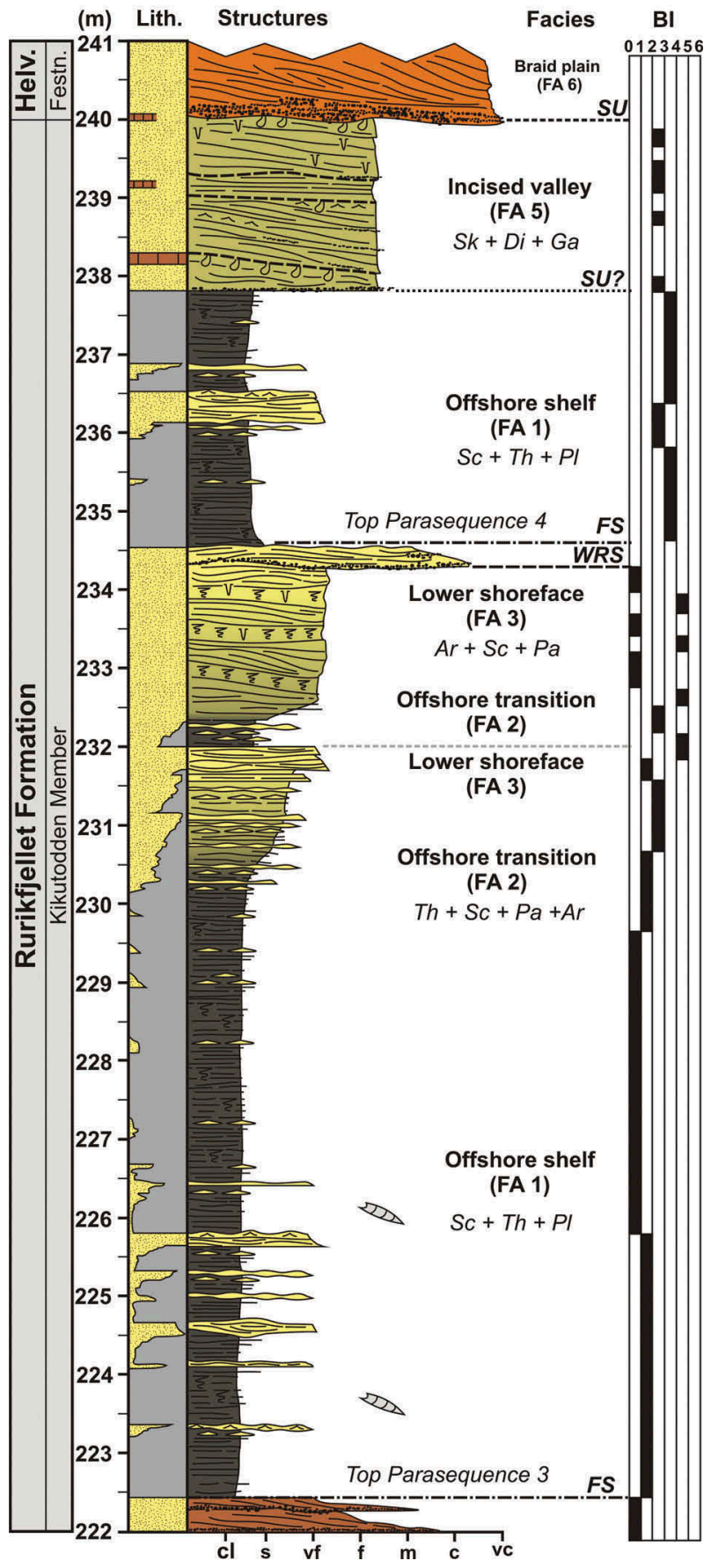

Figure 8. Detailed log of interval $222-241 \mathrm{~m}$ showing the transitional strata between the Rurikfjellet and Helvetiafjellet formations. FS: flooding surface; WRS: wave ravinement surface; SU: subaerial unconformity. Trace fossil abbreviations: Ar: Arenicolites; Di: Diplocraterion habichi; Ga: Gastrochaenolites; Pa: Palaeophycus; PI: Planolites; Sc: Schaubcylindrichnus; Th: Thalassinoides.

offshore transition (FA 2) and lower to upper shoreface (FAs 3-4) origin (Figs. 7, 9) in the Kikutodden Member.

The latter shallow marine associations are organized into three vertically stacked coarsening-, thickeningand shoaling-upward units that conform to parasequences (sensu Van Wagoner et al. 1990; PS 1-3, Figs. 7, 9). Each PS is up to $50 \mathrm{~m}$ thick (Figs. 7, 9) and comprises offshore transition deposits (FA 2) in its lower part and grades upward through lower shoreface to upper shoreface deposits (FA 3-4; Figs. 7, 9, Supplementary Fig. S2). However, PS 1 terminates in lower shoreface deposits (Figs. 7, 9). The PSs are separated by sharp contacts that record abrupt upward-deepening of facies, typically expressed by juxtaposition of offshore shelf (FA 1) or offshore transition (FA 2) with upper shoreface deposits (Figs. 7, 10a). Conglomeratic lags are present on top of each PS and probably record wave ravinement during intervening transgressions (Fig. 7). The limited palaeocurrent data obtained from wave-ripple crests (FA 3, Fig. 7) indicates that the lower shoreface segment of PS 2 was oriented roughly northwest-south-east, changing to north-south in PS 3. Palaeocurrent data obtained from tabular cross-stratification in the upper shoreface segment of the same PSs (FA 4, Fig. 7; see also Edwards 1976) show a large spread in palaeo-flow direction. In PS 2 the cross-strata show mainly migration parallel or obliquely to the northwest-south-east-oriented shoreline. In addition, there is a significant east-south-east-oriented component indicating offshore migration perpendicular to the shoreline. In PS 3, the cross-strata show mainly progradation towards the south and south-south-east.

A fourth, thinner $(<13 \mathrm{~m}$ thick $)$ and lessdeveloped PS occurs in the uppermost Rurikfjellet Formation (PS 4, Figs. 7, 8, 10). This unit only contains offshore transition to lowermost shoreface deposits (FAs 2-3, Fig. 8) and represents the distal part of a shoreline that prograded onto the shallow, subaqueous shelf created by flooding of the underlying PS 3. Belemnites and marine trace fossils (Thalassinoides, Palaephycus, Schaubcylindrichnus, Arenicolites and Rosselia), in addition to hummocky cross-stratified sandstones, all support a shallow marine to shelfal origin. The fourth PS is capped by a $0.2-0.3 \mathrm{~m}$ thick poorly sorted lithic conglomerate with a coarse-grained sandy matrix, suggested to represent a transgressive lag. The unit is overlain by a $4 \mathrm{~m}$ thick shale-dominated, heterolithic package (FA 2; Fig. 8).

The incised valley FA (FA 5) only occurs at the transition between the Rurikfjellet and Helvetiafjellet formations (Figs. 8, 10b). Supplementary Fig. S3). This unit erosively overlies the offshore transition deposits of FA 2 and its base marks an abrupt facies juxtaposition and upward-shoaling (Fig. 8). Strikingly similar deposits occur in the same stratigraphic interval at several other localities in Spitsbergen including Mälardalen (north central Spitsbergen, Fig. 1 for location), Baugen (eastern Spitsbergen, Fig. 1 for location) and at Louiseberget (central Spitsbergen, see Midtkandal \& Nystuen 2009; Fig. 1 for location). Furthermore, it is separated from the overlying braid plain deposits of the Festningen Member (FA 6) by the regionally extensive lower Barremian SU. The Festningen Member is up to $25 \mathrm{~m}$ thick and has a sheet-like appearance in the study area (Figs. 7, 9, 10c). 

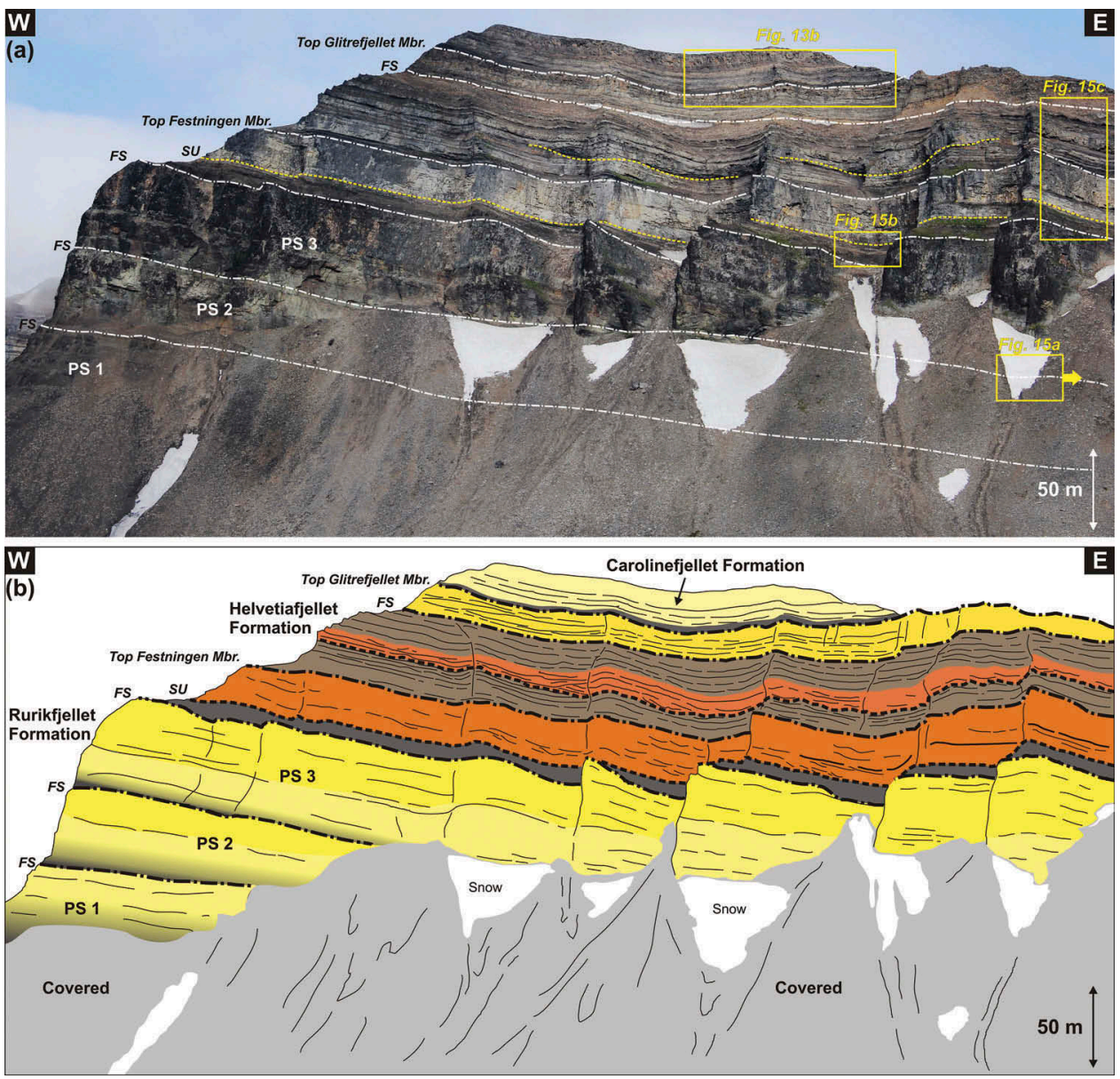

Figure 9. (a) Interpreted photos and (b) stratigraphic panel of the south face of Keilhaufjellet showing lithostratigraphic units, vertical facies distribution and sequence stratigraphic surfaces. The transitional strata, including parasequence 4, are not shown here because of their minor thickness, but are shown in Figs. 8, 10b). Yellow squares indicate positions of close-up photos shown in Fig. 10. FS: flooding surface; SU: subaerial unconformity; PS: parasequence.

An up to $1.4 \mathrm{~m}$ thick coaly shale unit (FA 7) conformably overlies the braid plain deposits of the Festningen Member (Fig. 9). However, in places the top surface of the Festningen Member is scoured and characterized by a matrix-supported conglomerate rich in in plant detritus. The overlying strata belong to the Glitrefjellet Member and are more heterolithic, consisting of alternating flood plain (FA 7), crevasse splay (FA 8) and fluvial distributary channel deposits (FA 9; Figs. 7, 9, 10c). A 5-6 m thick, poorly exposed shale unit of unknown origin (most likely FA 1 or 7; Figs. 7 ), separates the heterolithic coastal plain deposits (FAs 7-9) from the overlying delta front deposits (FA 10) in the uppermost part of the Helvetiafjellet Formation (Figs. 7, 9). The first evidence of more open marine conditions (i.e., Diplocraterion and Rhizocorallium; Fig. 5) is seen in these delta front deposits. This suggest that the shale represents transgression and marine flooding of the coastal plain, which translated the shoreline landward for several tens of kilometres. The delta front deposits (FA 10) thus record progradation of a deltaic shoreline onto the newly formed subaqueous shelf. The delta front deposits in the upper Glitrefjellet
Member are capped by an unsorted conglomerate rich in plant detritus which is overlain by an up to $7 \mathrm{~m}$ thick shale unit significantly darker in colour than any other shale in the investigated section (see black shale unit in Figs. 3b, 9, Supplementary Fig. S5b). The conglomerate represents a lag that formed during transgressive ravinement of the delta top. This explains why no delta top facies are recorded within the deltaic deposits (FA 10) of the Glitrefjellet Member. The dark coloured shale is followed by a $25 \mathrm{~m}$ thick (minimum thickness due to Cenozoic uplift and erosion) succession of inner shelf to nearshore deposits (FA 11; Figs. 7, 9). This association is very similar to the underlying delta front of FA 10, but differs in being more heterolithic (Fig. 7, Supplementary Fig. S5c), with less plant detritus and a more diverse marine trace fossil assemblage. The inner shelf to nearshore deposits (FA 11) belongs to the Dalkjegla Member of the Carolinefjellet Formation (Figs. 3b, 7, 9). The overall vertical facies arrangement above the lower Barremian subaerial unconformity at the base of the Helvetiafjellet Formation indicates a long-term upward increase in marine influence (Figs. 7, 9). 

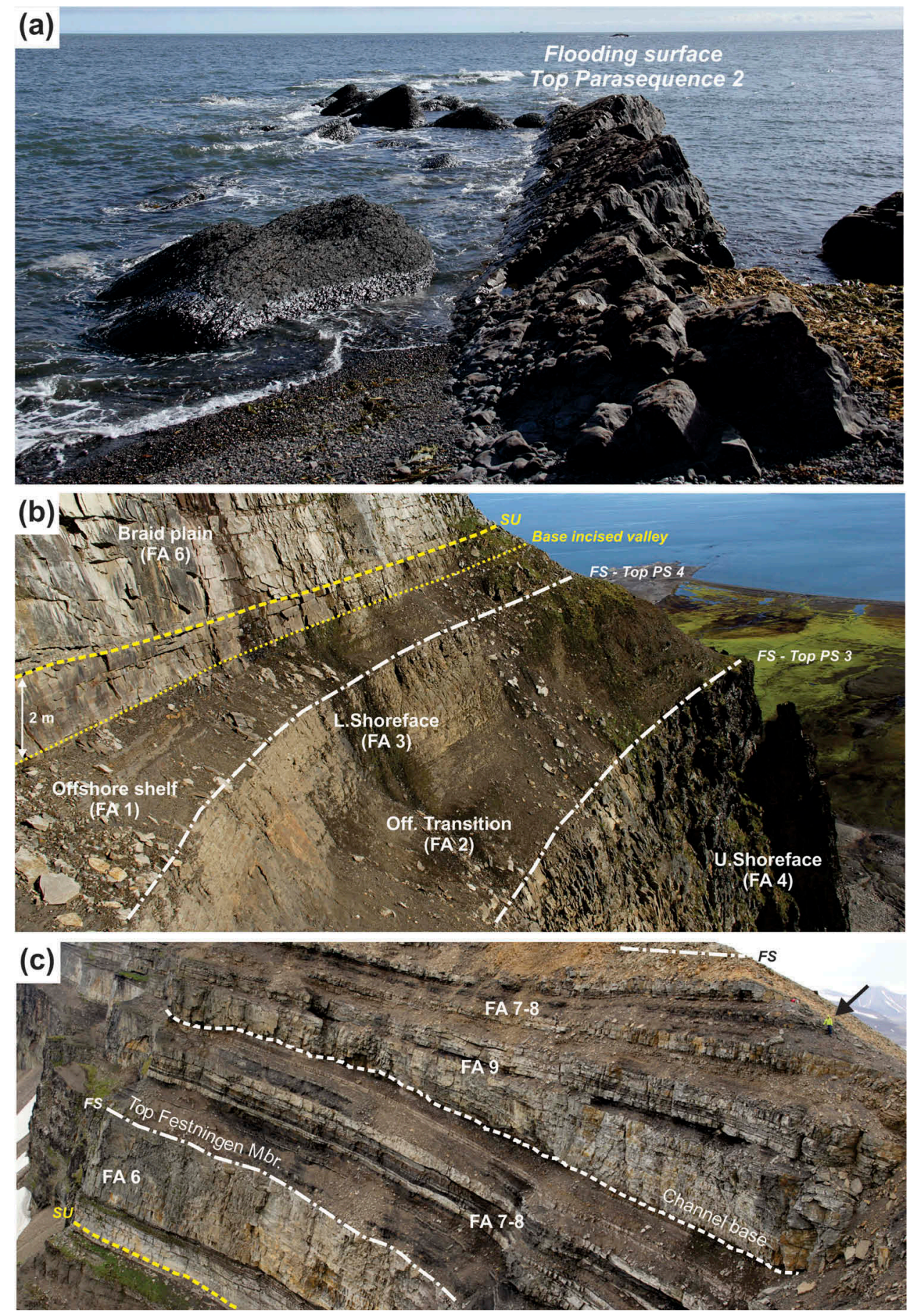

Figure 10. (a) Photo from Kikutodden showing the flooding surface between parasequence 2 and 3. (b) Outcrop photo showing the transitional strata between the Rurikfjellet and Helvetiafjellet formations, together with facies and interpreted sequence stratigraphic surfaces. Note the thin package of incised valley deposits (FA 5). (c) Close-up showing facies development in the lower part of the Helvetiafjellet Formation, which is characterized by various fluvial (FA 6) and marginal marine deposits (FA 7-9). Note person for scale (black arrow). FS: flooding surface; SU: subaerial unconformity; PS: parasequence.

\section{Discussion}

\section{Depositional model}

The overall progradational PS stacking in the Rurikfjellet Formation suggests deposition during a long-term sea-level highstand. The lower Barremian $\mathrm{SU}$ and the succeeding aggradational to retrogradational facies stacking in the Helvetiafjellet Formation (Fig. 7) indicate that the normal regression was interrupted by a dramatic relative sea-level fall followed by a long term relative sea-level rise (Fig. 2). This development is similar to that reported elsewhere in Spitsbergen in previous studies (Steel \& Worsley 1984; Nemec 1992; Gjelberg \& Steel 1995; Midtkandal et al. 2007; Midtkandal \& Nystuen 2009). Because of the similar development seen across large parts of the outcrop window in Spitsbergen, it may be argued that the various lithostratigraphic units comprised aerially extensive, low-angle facies belts (Midtkandal \& Nystuen 2009). This implies 

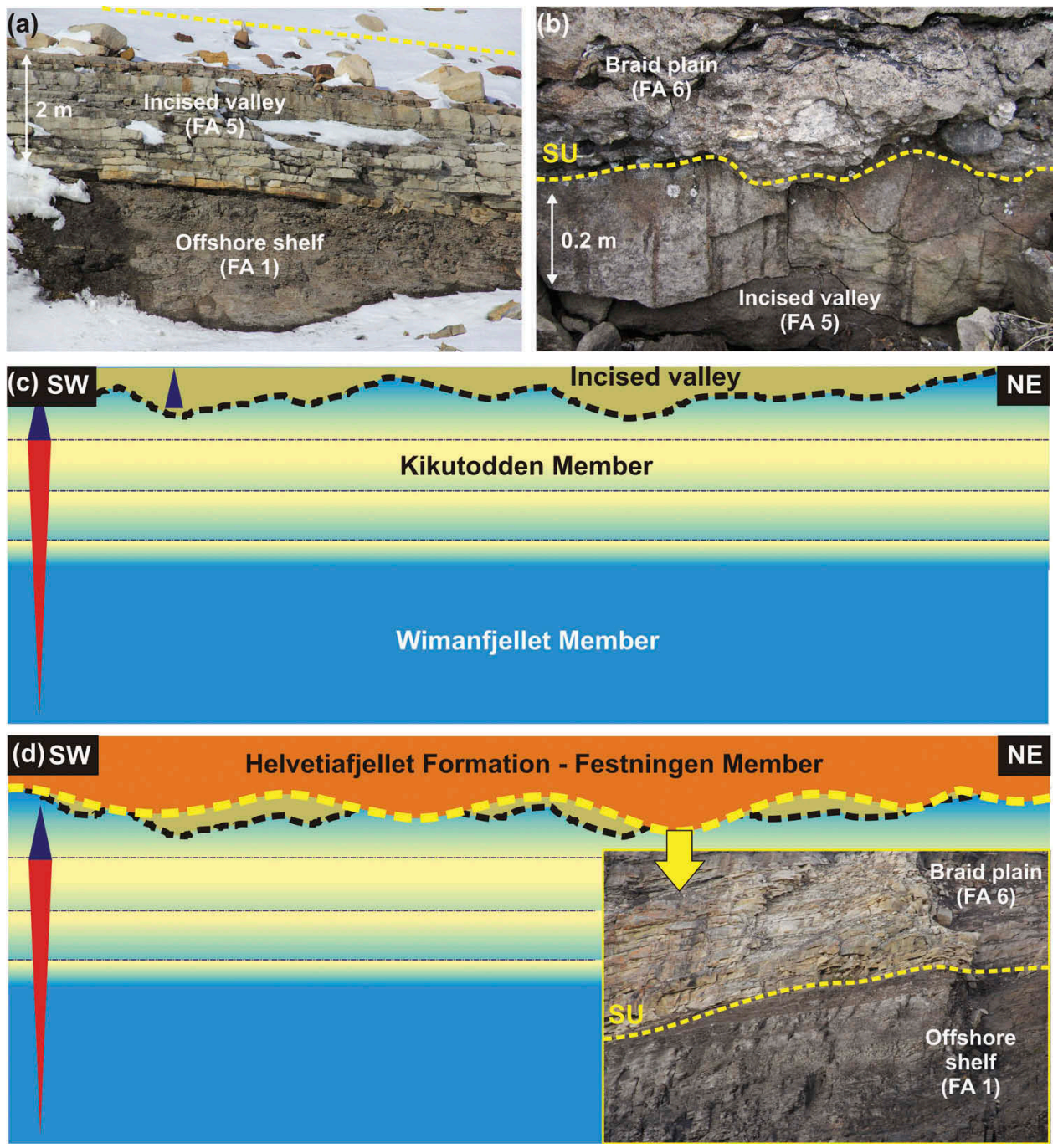

Figure 11. Sharp-based sandstone packages, interpreted as incised valley deposits, occur beneath the lower Barremian subaerial unconformity at several other localities across Spitsbergen, including (a) Mälardalen and (b) Baugen (see Fig. 1 for location). The incised valley formed as a response to a higher frequency relative sea-level fall, and was filled during the succeeding sea-level rise. The incised valley deposits probably covered large areas (c), but were later eroded during formation of the overlying subaerial unconformity at the base of the Festningen Member (d).

that even a minor change in relative sea-level could result in a regional (at the scale of the outcrop window) re-organization of the facies belts, eventually giving rise to a sheet-like architecture similar to the layer-cake model previously discussed (Nagy 1970; Midtkandal \& Nystuen 2009; Figs. 2, 4). It has been suggested that the uplift-related erosion that created the subaerial unconformity was minimal in southern Spitsbergen (Edwards 1976; Gjelberg \& Steel 1995). However, the SU is present within the study area, and an incised valley (FA 5) that formed prior to the main unconformity has also been recognized (Figs. 3b, 7, 8, 11, Supplementary Fig. S3). This indicates a far more complex development of the subaerial unconformity in the study area than first suggested (Edwards 1976; Gjelberg \& Steel 1995). This also implies that the eroded sediments periodically must have bypassed southern Spitsbergen and been deposited in areas of higher accommodation space on the Barents Shelf, as illustrated in Fig. 12.

\section{Depositional evolution of the Rurikfjellet formation} The lower shale-dominated Wimanfjellet Member has previously been interpreted to represent open marine, outer shelf deposits (e.g., Dypvik et al. 1991). Traditionally, offshore shales are interpreted in terms of suspension fall-out deposits aggrading in quiet waters typically below storm wave-base (e.g., Edwards 1976). However, recent studies have highlighted the importance of fluid muds, migrating floccule ripples and wave-modified gravity flows as important factors for mud transport to the outer shelf and beyond (Schieber et al. 2007; MacQuaker et al. 2010). Mudstone-dominated, low-gradient $\left(<1^{\circ}\right)$ clinoforms with heights of 150-200 $\mathrm{m}$ and slope lengths of $30-40 \mathrm{~km}$ are reported in the Lower 
Cretaceous succession on the Barents Shelf (Marin \& Escalona 2014). Similar low-angle mudstone-dominated clinoforms may occur in the Wimanfjellet Member. The upward increase in siltstone and woody material as reported by Dypvik et al. (1991), as well as the gradual transition into shallow marine deposits of the overlying Kikutodden Member (e.g., FA 2-4; Fig. 7), clearly indicate overall regressive conditions (Edwards 1976; this study). However, if clinoforms are present in the Wimanfjellet Member, their scale in combination with outcrop limitations makes detection of such features difficult, if not impossible.

The progradationally stacked PSs of the Kikutodden Member record repeated episodes of shoreline progradation onto the shelf (Figs. 3b, 7, 9; Edwards 1976). The lack of any major facies-juxtapositions attributable to relative sea-level falls (e.g., incisions, subaerial exposure surfaces), and the thickness of the PSs (40-50 m; Fig. 7) suggest that the shoreline tongues prograded under flat to ascending shoreline trajectory conditions (sensu Helland-Hansen \& Martinsen 1996). The lack of backshore and coastal plain deposits in any of the parasequences indicate high rates of sediment accumulation relative to the rates of relative sea-level change. The result was lowangle facies lines, limited accommodation space for backshore and coastal plain deposits to accumulate, and rapid basinward accretion. Alternatively, the lack of backshore deposits relate to transgressive erosion as evident from the transgressive lag at top of each PS, or that conditions at all times were too deep and that the parasequences represent an infralittoral prograding wedge that developed in front of the actual shoreline (Hernández-Molina et al. 2000; Patruno et al. 2015).

Palaeocurrent data from the cross-strata in PS 2 and PS 3 show that the upper shoreface of both these PSs prograded obliquely or parallel to the roughly north-south-trending lower shoreface-part of the shoreline (Fig. 7). Cross-strata in the upper shoreface are here attributed to migrating dunes that formed longshore bars (e.g., Clifton 2006). On the basis of the wide spread with a strong south to south-eastoriented component, Edwards (1976) suggested strong tidal influence. Longshore bars commonly develop adjacent to river mouths and form by a combination of various processes including tidal currents, longshore drift and breaking waves (e.g., HomMa \& Sonu 1962).

In the upper Rurikfjellet Formation, coarse-grained and quartz-rich PSs of similar character to the ones investigated here also occur at Strykejernet in Hornsund (Mørk 1978). These PSs represents the northward extension of the PS set described herein. In the Isfjorden area in the northernmost part of the outcrop belt, PSs in the upper Rurikfjellet Formation is much finer grained and heterolithic. These parasequences pinch out south towards central Spitsbergen where the same stratigraphic interval is shale-dominated (Dypvik et al. 1991; Midtkandal et al. 2008). In order to explain these regional stratigraphic differences, two laterally separate shallow marine wedges are suggested: one in north-west Spitsbergen and one in southern Spitsbergen (Fig. 6b). A potential source area for the latter coarse-grained and more quartz rich wedge could be north-east Greenland, which was located much closer to southern Spitsbergen in the Early Cretaceous (Fig. 5; Dypvik et al. 2002). More detailed provenance studies must be conducted to confirm this. None of the PSs terminate in the study area and there are no major facies changes between Strykejernet (Mørk 1978) and Keilhaufjellet/ Kikutodden (Edwards 1976; this study), a distance of about $60 \mathrm{~km}$ (Fig. 1). This confirms deposition on lowgradient ramp with aerially extensive facies belts that may support the presence of a maximum regression point for the shoreline several tens of kilometres to the south of Spitsbergen (Fig. 6).

\section{Transition between Rurikfjellet and Helvetiafjellet formations}

Edwards (1976) interpreted his uppermost coarsening-upward cycle (PS 4 in this study; Figs. 7, 8, 10b) in the Rurikfjellet Formation to represent a lagoon and barrier system that formed during a minor relative sea-level fall. More proximal barrier deposits were inferred to be present further down-dip outside the outcrop belt (Edwards 1976). However, no convincing evidence for such deposits was recorded in this study. The recognition of a fully marine trace fossil assemblage (Thalassinoides, Palaeophycus, Schaubcylindrichnus, Arenicolites and Rosselia), belemnites and storm-generated structures in PS 4 instead suggest an open marine shelf origin (FA $1-2$; Fig. 8). It is suggested that PS 4 represent the distal parts of a shoreline tongue that prograded onto the shelf that was created by flooding of PS 3 (Figs. 7-9). The limited thickness of the PS $4(<10 \mathrm{~m}$; Fig. 7$)$ is attributed to shallow water and limited accommodation space on the newly developed shelf. The shoreline of PS 4 also suffered from less sediment supply compared to PS 3 and retreated long before it managed to prograde to an outer shelf position.

In the present study, incised valley deposits FA 5; Fig. 8, Supplementary Fig. S3) are interpreted to occur below the subaerial unconformity at the base of the Helvetiafjellet Formation (Figs. 7, 8 10b), Supplementary Fig. S3). Because of the poor exposures, Edwards (1976) did not recognize such erosively based deposits in his coastal section. The erosive base of the incised valley may have formed during subaerial exposure with subsequent modification by wave or tidal processes. The presence of an 
extra-basinal conglomerate along its base (Supplementary Fig. S3b) points to a more complex history than simple wave or tidal ravinement (e.g., Plint 1988; Plint \& Nummedal 2000). Multiple omission surfaces demarcated by trace fossils of the Glossifungites Ichnofacies (Supplementary Fig. S3a) suggest that infill of the interpreted valley took place during slow and stepwise relative sea-level rise, prior to the uplift that formed the lower Barremian SU. The trace fossil assemblage also points to firm-ground and sediment-starved conditions, which is in agreement with deposition during relative sea-level rise (MacEachern et al. 2007). Midtkandal et al. (2008) documented incised valley systems with similar, but thicker (up to $25 \mathrm{~m}$, but typically 12-15 m thick) deltaic to estuarine deposits in the Louiseberget area $120 \mathrm{~km}$ north of the study area (see Fig. 1 for location). These incised valley deposits also occur below the lower Barremian SU (the Louiseberget Bed of the Festningen Member, see Midtkandal et al. 2008; Midtkandal \& Nystuen 2009). It is difficult to assess whether the incised valley deposits in southernmost Spitsbergen correspond to the Louiseberget Bed or a separate system. However, their recognition confirms the presence of a large incised valley or several smaller partly coalescing incised valleys of semi-regional extent (Midtkandal \& Nystuen 2009; Fig. 11).

\section{Depositional evolution of the Helvetiafjellet formation}

The basal Festningen Member is bounded below by the lower Barremian SU and on top by a coaly shale interval (Figs. 3b, 7, 9). The former developed during peak uplift in the Barremian (Gjelberg \& Steel 1995; Midtkandal \& Nystuen 2009; Fig. 6). The latter is interpreted to represent the landward expression of a marine flooding surface. However, the extent of this flooding surface is debated. The layer-cake/aggrading model suggests it is of regional importance (Midtkandal et al. 2007; Midtkandal \& Nystuen 2009; Fig. 4), whereas the diachronous model suggests it is only locally important (Gjelberg \& Steel 1995, 2012; Fig. 4).

It has previously been suggested that the fluvial sandstones of the Festningen Member (FA 6) was partly deposited in a wide, low-relief and regionally extensive incised valley complex (Gjelberg \& Steel 1995; Midtkandal et al. 2007; Midtkandal \& Nystuen 2009). The unit forms a regionally extensive sandstone sheet with a complex multi-storey and multilateral internal architecture (Figs. 3b, 9; Nemec 1992). As pointed out by Midtkandal \& Nystuen (2009) the architecture points to deposition under limited vertical accommodation. It is therefore suggested here that the top of the Festningen Member represents an expansion surface that records an abrupt increase in lateral accommodation. The surface probably formed as sea level rose and the fluvial deposits eventually filled the topography that had formed during subaerial exposure. The continued increase in both lateral and vertical accommodation is evident in the Glitrefjellet Member, which is more heterolithic and consists of various delta plain deposits (FA 7-8; Fig. 7) that only locally are incised by singlestorey channels or thinner and less pronounced multi-storey channel belts (FA 9; Figs. 7, 9). The large amount of preserved fine-grained sediments and the single storey channel architecture points to a high-accommodation system (e.g., Martinsen et al. 1999; Bridge 2006).

It has been postulated that the Helvetiafjellet Formation formed during a long-term relative sealevel rise (spanning the early Barremian to early Aptian) and that the facies belts are retrogradationally stacked (Gjelberg \& Steel 1995). However, no pinch-out geometries as pictured in the diachronous model (Fig. 4) have so far been observed in any outcrops, including the study area. The vertical facies arrangement in the upper part of the Helvetiafjellet Formation show an overall upwards increase in marine influence. However, a large-scale retrogradational stacking pattern can be deduced from the presence of delta front deposits in the uppermost Glitrefjellet Member (Figs. 2, 3b, 7, 9, 12). In central Spitsbergen, Midtkandal et al. (2007) reported that the same interval shows a clear aggradational architecture and suggested mainly autogenic controls on the facies distribution.

\section{Depositional evolution of the Carolinefjellet formation}

Only the lowermost part of the Dalkjegla Member is present in the study area on account of Cenozoic uplift and erosion, which limits the discussion to this particular interval (Figs. 3a, 7). There have been few detailed studies on the Dalkjegla Member and most studies have interpreted it to represent open marine shelf deposits (e.g., Nagy 1970; Nemec et al. 1988). Some of the sandstone-dominates parts of the unit have previously been interpreted to represent offshore bars on a storm-dominated shelf (e.g., Nøttvedt \& Kriesa 1987), as well as retreating barrier complexes (Mutrux et al. 2008). The Dalkjegla Member is generally regarded to be the transgressive and lateral distal equivalent to the underlying deltaic Helvetiafjellet Formation (Gjelberg \& Steel 1995). In the present study, the basal surface of the unit represents a flooding surface that formed by transgression of the underlying delta top of FA 10 (i.e., the Helvetiafjellet Formation; Fig. 7, Supplementary Fig. S5b). Wave ravinement during the transgression removed parts of the delta plain and left behind a transgressive lag rich in plant detritus 


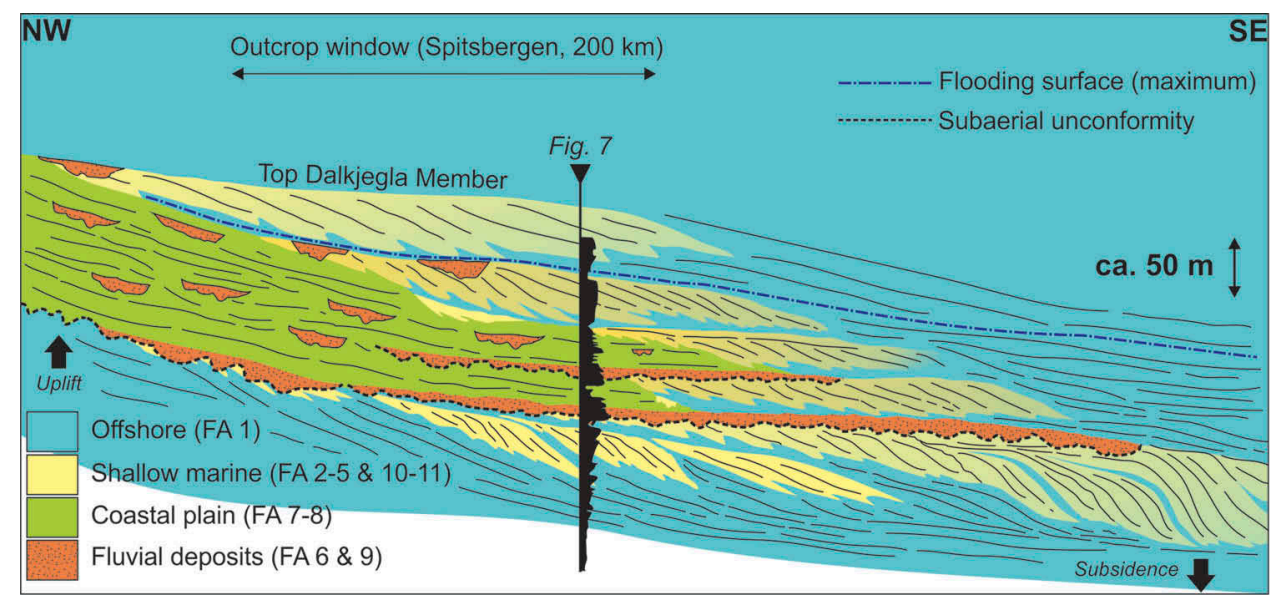

Figure 12. Schematic depositional-dip oriented cross-section showing the possible offshore regional development of the Lower Cretaceous in Spitsbergen. The subaerial unconformity at the base of the Helvetiafjellet Formation may link with a thick forced regressive wedge in the offshore subsurface. Depending on shelf gradient (or equilibrium profile), sediment supply, magnitude of relative sea-level fall and amount of transgressive erosion, the forced regressive wedge may or may not be attached to the preceding delta front. Many of the same factors also control whether the forced regressive wedge will appear with a smooth or stepped top and the extent of possible separation zones between the successive shoreline bodies. Sediment bypass or low rates of deposition occur in the separation zone, giving way to condensed sections and foreshortened stratigraphic successions.

(Supplementary Fig. S5a). The flooding also created a shallow subaqueous shelf characterized by open to restricted marine conditions, and during this period the black shale in the lower Dalkjegla Member was deposited. The succeeding sand-rich part of the Dalkjegla Member records renewed nearshore and inner shelf progradation (FA 11) onto the shallow subaqueous shelf (Fig. 12). The upper part of the unit is not preserved in the study area, but in central Spitsbergen the sandstones grade upward into the shales of the overlying Innkjegla Member (Fig. 2; Maher et al. 2004) and the two members form a regionally extensive regressive to transgressive wedge. It is possible that this wedge represents the distal equivalent of the back-stepping deltaic system of the underlying Helvetiafjellet Formation as previously suggested (e.g., Gjelberg \& Steel 1995; Maher et al. 2004; Mutrux et al. 2008). Therefore, the large-scale regressive-transgressive architecture in the lower Carolinefjellet Formation indicates that retrogradational back-stepping also occurred at a lower frequency than what has previously been reported in the Helvetiafjellet Formation alone (see Gjelberg \& Steel 1995).

\section{Implications for onshore-offshore correlations}

Whether a shelf edge developed offshore close to the present day coastline, as suggested by Steel et al. (2000), is difficult to assess mainly on account of the lack of data and because large parts of the Lower Cretaceous between Spitsbergen and the Bjarmeland Platform have been eroded in the Cenozoic. However, slope facies or depositional features like seismic-scale clinoform geometries, canyons, slumps, or shelf-edge deltas indicating a shelf- margin setting have not been documented in any outcrops. The exceptions are turbidites and debrites associated with the infill of small (a few hundred metres wide) syn-sedimentary collapse scars in eastern Spitsbergen (Nemec et al. 1988). These collapse scars have been suggested to be related to headwall erosion and retrogradational slumping within shelfedge canyons initiated by tectonic activity (Steel et al. 2000; Fig. 4). However, more recent studies by Onderdonk \& Midtkandal (2010) have demonstrated that the collapses was triggered by tectonic activity along the long-lived lineaments and that they never involved delta front or shelf-edge strata as previously inferred (Nemec et al. 1988; Gjelberg \& Steel 1995).

An explanation for the general lack of shelf-edge deposits may therefore relate to the low-angle ramp setting which prevented the formation of prominent shelf-edge geometries and instead promoted extensive, low-angle facies lines (i.e., low-angle clinoforms). The lower Barremian SU (e.g., Figs. 3b, 6) indicates that uplift and erosion also occurred in southern Spitsbergen. The eroded sediments must have been deposited in deeper basins south of the present day outcrop belt. For most of the Early Cretaceous, the basins on the Barents Shelf were subsiding and thus offered accommodation space for the eroded sediments. On the basis of the inferred low-angle ramp setting in combination with the regional extent of the SU and high rate of sediment supply, it is suggested that the maximum regressive point for the system was located several tens to hundreds of kilometres further offshore than what is indicated in the transgressive/ shelf-edge depositional model (Gjelberg \& Steel 1995; Steel et al. 2000; Fig. 4). The present study is therefore more in agreement with the layer-cake/aggrading model in terms of the offshore extent of the system 
(Fig. 12; Midtkandal \& Nystuen 2009; see also Edwards 1975). The incised valley deposits (FA 5) below the main SU in southern Spitsbergen records multiple episodes of uplift, erosion and sediment bypass. Therefore, the present study also suggests a more direct and genetic link between the investigated onshore strata and the time-equivalent shelf-marginscale clinoforms reported in the Fingerdjupet Subbasin and on the western part of the Bjarmeland Platform (Marin \& Escalona 2014). It is also suggested that the PSs in the Rurikfjellet Formation can be an useful outcrop analogue to steep-angled (potentially sandrich) clinoforms reported along some of the basinal highs along the western margin of the Barents Shelf (e.g., Bryn \& Haaland 2016).

\section{Conclusions}

The Lower Cretaceous in southernmost Spitsbergen comprises, in ascending stratigraphic order, the Rurikfjellet, Helvetiafjellet and Carolinefjellet formations. The three formations together form a largescale first-order regressive-transgressive sequence. Detailed sedimentological investigations of the Lower Cretaceous demonstrate the following.

The lower Rurikfjellet Formation, the Wimanfjellet Member, consists of offshore shelf deposits that grade upward into offshore transition and shoreface deposits of the Kikutodden Member. The nearshore deposits in the Kikutodden Member stack into 40-50 m thick shoaling-upward parasequences (PS), which record the successive basinward progradation of the shoreline. Each PS is terminated by an abrupt upward facies deepening formed during flooding and shoreline retreat. The lack of backshore and coastal plain deposits, as well as facies juxtapositions attributable to relative sea-level falls, indicates that the PSs prograded under flat to ascending trajectory conditions typical for relative sea-level highstand.

Sharp-based, shallow to marginal marine deposits occur just below the regionally extensive subaerial unconformity at the base of the Helvetiafjellet Formation. These deposits are bounded below by an erosive surface of unknown origin. On the basis of the presence of a basal lag consisting of extra-basinal clasts it is argued that the surface represents a subaerial unconformity rather than a wave ravinement surface. The surface thus marks the base of an incised valley that formed and was filled prior to formation of the main subaerial unconformity. Omission surfaces demarcated by trace fossils attributable to the Glossifungites Ichnofacies within the incised valley fill indicate firmground conditions and slow sediment accumulation.

The lowermost sandstone-dominated unit of the Helvetiafjellet Formation, the Festningen Member, consists of braid plain deposits and is bounded below by the regionally extensive subaerial unconformity. The architecture of the braid plain deposits indicates limited vertical accommodation during deposition, possibly indicating sediment accumulation during early stages of relative sea-level rise. The subaerial unconformity indicates that uplift and erosion also took place in southern Spitsbergen, implying that eroded sediments must have been transported southward and deposited in basinal areas with available accommodation space. It is therefore suggested that the onshore system may be genetically linked to shelf-margin-scale clinoforms in the Lower Cretaceous sequences offshore.

The Festningen Member is capped by a coaly shale interval that is interpreted to represent the landward expression of a marine flooding surface. The surface is also regarded as an expansion surface, marking a change from a low-accommodation (the Festningen Member) to a high-accommodation (the Glitrefjellet Member) fluvial system.

The upper Helvetiafjellet Formation, the Glitrefjellet Member, shows clear evidence of an upward increase in marine influence, indicating deposition during a long-term relative sea-level rise. The presence of delta front deposits in the upper Glitrefjellet Member may be attributable to retrogradational retreat at second- or third-order scale. The delta front unit is capped by a transgressive lag that formed by marine flooding and erosion of the delta plain. The flooding formed a shallow subaqueous shelf and marks a return to open marine shelf conditions. The succeeding sand-rich part of the Dalkjegla Member (Carolinefjellet Formation) records renewed nearshore and inner shelf progradation onto the shallow subaqueous shelf.

\section{Acknowledgements}

The authors are grateful to all the sponsors of the LoCrA consortium who provided financial support to carry out fieldwork. We are also grateful to Lundin Norway for their financial support of a postdoctoral research position to the first author. David Worsley is thanked for constructive comments and proof reading, and journal reviews by Atle Folkestad and Guy Plint greatly improved the clarity of the paper. Parts of this study were funded by ARCEx partners and the Research Council of Norway (grant no. 228107).

\section{Disclosure statement}

No potential conflict of interest was reported by the authors.

\section{Funding}

This work was supported by the LoCrA consortium, ARCEx partners and the Research Council of Norway (228107). 


\section{References}

Anell I., Braathen A., Olaussen S. \& Osmundsen P.T. 2013. Evidence of faulting contradicting a Triassic quiescent northern Barents Shelf. First Break 31, 67-76.

Århus N. 1991. Dinoflagellate cyst stratigraphy of some Aptian and Albian sections from north Greenland, southeastern Spitsbergen and the Barents Sea. Cretaceous Research 12, 209-225.

Bergh S.G., Braathen A. \& Andresen A. 1997. Interaction of basement-involved and thin-skinned tectonism in the Tertiary fold-and-thrust belt, central Spitsbergen, Svalbard. American Association of Petroleum Geologists Bulletin 81, 637-661.

Braathen A., Bergh S.G. \& Maher H.D. Jr. 1999. Application of a critical wedge taper model to the Tertiary transpressional fold-thrust belt on Spitsbergen. Geological Society of America Bulletin 111, 1468-1485.

Bridge J.S. 2006. Fluvial facies models: recent developments. In H.W. Posamentier \& R.G. Walker (eds.): Facies models revisited. Pp. 85-170. Tulsa: Society for Sedimentary Geology.

Bryn B.K.L. \& Haaland S.S. 2016. Fingerdjupet Sub-basin, Norwegian Barents Sea: a laboratory for the exploration of an untested Lower Cretaceous play. Paper presented at the Arctic Exploration-Understanding the Barents Sea Potential conference, 31 May-2 June, Tromsø.

Clifton H.E. 2006. A reexamination of facies models for clastic coasts. In H.W. Posamentier \& R.G. Walker (eds.): Facies models revisited. Pp. 293-337. Tulsa: Society for Sedimentary Geology.

Ditchfield P.W. 1997. High northern palaeolatitude Jurassic-Cretaceous palaeotemperature variation: new data from Kong Karls Land, Svalbard. Palaeogeography, Palaeoclimatology, Palaeoecology 130, 163-175.

Dypvik H., Håkansson E. \& Heinberg C. 2002. Jurassic and Cretaceous palaeogeography and stratigraphic comparisons in the North Greenland-Svalbard region. Polar Research 21, 91-108.

Dypvik H., Nagy J., Eikeland T.A., Backer-Owe K. \& Johansen H. 1991. Depositional conditions of the Bathonian to Hauterivian Janusfjellet Subgroup, Spitsbergen. Sedimentary Geology 72, 55-78.

Edwards M.B. 1975. Gravel fraction on the Spitsbergen Bank, NW Barents Shelf. Norges Geologiske Undersøkelser 316, 205-217.

Edwards M.B. 1976. Depositional environments in Lower Cretaceous regressive sediments, Kikutodden, Sørkapp Land, Svalbard. Norsk Polarinstitutt Årbok 1974, 35-50.

Edwards M.B. 1978. A regional survey of composition, provenance and diagenesis of sandstones in the Lower Cretaceous Helvetiafjellet Formation, Svalbard. Norsk Polarinstitutt Årbok 1977, 343-345.

Faleide J.I., Tsikalas F., Breivik A.J., Mjelde R., Ritzmann O., Engen Ø., Wilson J. \& Eldholm O. 2008. Structure and evolution of the continental margin off Norway and the Barents Sea. Episodes 31, 82-91.

Faleide J.I., Vågnes E. \& Gudlaugsson S.T. 1993. Late Mesozoic-Cenozoic evolution of the southwestern Barents Sea in a regional rift-shear tectonic setting. Marine and Petroleum Geology 10, 186-214.

Francis J.E. \& Frakes L.A. 1993. Cretaceous climates. In V. P. Wright (ed.): Sedimentology review. Vol. 1. Pp. 17-30. Oxford: Blackwell.

Gjelberg J. \& Steel R.J. 2012. Depositional model for the Lower Cretaceous Helvetiafjellet Formation on Svalbard -diachronous vs. layer-cake models. Norwegian Journal of Geology 91, 41-54.

Gjelberg J. \& Steel R.J. 1995. Helvetiafjellet Formation (Barremian-Aptian), Spitsbergen: characteristics of a transgressive succession. In R.J. Steel et al. (eds.): Sequence stratigraphy on the northwest European Margin. Pp. 571-593. Amsterdam: Elsevier.

Golonka J., Bocharova N.Y., Ford D., Edrich M.E., Bednarczyk J. \& Wildharber J. 2003. Paleogeographic reconstructions and basins development of the Arctic. Marine and Petroleum Geology 20, 211-248.

Grantz A., Hart P.E. \& Childers V.A. 2011. Geology and tectonic development of the Amerasia and Canada basins, Arctic Ocean. In A.M. Spencer et al. (eds.): Arctic petroleum geology. Pp. 771-799. London: Geological Society.

Grogan P., Nyberg K., Fotland B., Myklebust R., Dahlgren S. \& Riis F. 1998. Cretaceous magmatism south and east of Svalbard: evidence from seismic reflection and magnetic data. Polarforschung 68, 25-34.

Grøsfjeld K. 1992. Palynological age constraints on the base of the Helvetiafjellet Formation (Barremian) on Spitsbergen. Polar Research 11, 11-19.

Hallam A. 1985. A review of Mesozoic climates. Journal of the Geological Society 142, 433-445.

Hammer Ø., Nakrem H.A., Little C.T.S., Hryniewicz K., Sandy M.R., Hurum J.H., Druckenmiller P., Knutsen E. M. \& Høyberget M. 2011. Hydrocarbon seeps from close to the Jurassic-Cretaceous boundary. Palaeogeography, Palaeoclimatology, Palaeoecology 306, 15-26.

Harland M., Francis J.E., Bretnall S.J. \& Beerling D.J. 2007. Cretaceous (Albian-Aptian) conifer wood from Northern Hemisphere high latitudes: forest composition and palaeoclimate. Review of Palaeobotany and Palynology 143, 167-196.

Helland-Hansen W. \& Martinsen O.J. 1996. Shoreline trajectories and sequences; description of variable depositional-dip scenarios. Journal of Sedimentary Research 66, 670-688.

Hernández-Molina F.J., Fernández-Salas L.M., Lobo F., Somoza L., Díaz-del-Rio V. \& Alveirinho Dias J.M. 2000. The infralittoral prograding wedge: a new largescale progradational sedimentary body in shallow marine environments. Geo-Marine Letters 20, 109-117.

Hom-Ma M. \& Sonu C. 1962. Rhythmic pattern of longshore bars related to sediment characteristics. Coastal Engineering Proceedings 8, 248-278.

Hurum J.H., Druckenmiller P.S., Hammer Ø., Nakrem H.A. \& Olaussen S. 2016. The theropod that wasn'tan ornithopod tracksite from the Helvetiafjellet Formation (Lower Cretaceous) of Boltodden, Svalbard. In B.P. Kear et al. (eds.): Mesozoic biotas of Scandinavia and its Arctic territories. Pp. 189-206. London: Geological Society.

Lawver L.A., Grantz A. \& Gahagan L.M. 2002. Plate kinematic evolution of the present Arctic region since the Ordovician. In E.L. Miller et al. (eds.): Tectonic evolution of the Bering Shelf-Chukchi Sea-Arctic margin and adjacent landmasses. Pp. 333-358. Boulder: Geological Society of America.

MacEachern J.A., Bann K.L., Pemberton S.G. \& Gingras M. K. 2007. The ichnofacies paradigm: high-resolution paleo environmental interpretation of the rock record. In J.A. MacEachern et al. (eds.): Applied ichnology. SEPM Short Course Notes 52. Pp. 27-64. Tulsa: Society for Sedimentary Geology. 
Maher H.D. Jr. 2001. Manifestations of the Cretaceous High Arctic large igneous province in Svalbard. The Journal of Geology 109, 91-104.

Maher H.D. Jr., Hays T., Shuster R. \& Mutrux J. 2004. Petrography of the Lower Cretaceous sandstones of Spitsbergen. Polar Research 23, 147-165.

Manum S.B. \& Throndsen T. 1978. Rank of coal and dispersed organic matter and its geological bearing in the Spitsbergen Tertiary. Norsk Polarinstitutt Årbok 1977, 159-177.

Marin D. \& Escalona A. 2014. Architecture and distribution analysis of the Lower Cretaceous clinoforms in the Western Barents Sea. Poster presented at the 6th Saint Petersburg International Conference \& Exhibition, 7-10 April, Petersburg.

Markwick P.J. \& Rowley D.B. 1998. The geological evidence for Triassic to Pleistocene glaciations: implications for eustasy. In J.L. Pindell \& C.L. Drake (eds.): Paleogeographic evolution and non-glacial eustasy, northern South America. SEPM Special Publication 58. Pp. 1743. Tulsa: Society for Sedimentary Geology.

Marshall C., Large D.J., Snape C.E., Meredith W., Uguna C., Spiro B.F., Orheim A., Jochmann M., Mokogwu I., Wang Y. \& Friis B. 2015. Geochemistry and petrology of Palaeocene coals from Spitsbergen. Part 1: oil potential and depositional environment. International Journal of Coal Geology 143, 22-33.

Martinsen O.J., Ryseth A., Helland-Hansen W., Flesche H., Torkildsen G. \& Idil S. 1999. Stratigraphic base level and fluvial architecture: Ericson Sandstone (Campanian), Rock Springs Uplift, SW Wyoming, USA. Sedimentology 46, 235-263.

Michelsen J.K. \& Khorasani G.K. 1991. A regional study on coals from Svalbard: organic facies, maturity and thermal history. Bulletin Société de la Géologie de France 162, 385-397.

Midtkandal I. \& Nystuen J.P. 2009. Depositional architecture of a low-gradient ramp shelf in an epicontinental sea: the lower Cretaceous of Svalbard. Basin Research 21, 655-675.

Midtkandal I., Nystuen J.P. \& Nagy J. 2007. Paralic sedimentation on an epicontinental ramp shelf during a full cycle of relative sea-level fluctuation; the Helvetiafjellet Formation in Nordenskiöld Land, Spitsbergen. Norwegian Journal of Geology 87, 343-359.

Midtkandal I., Nystuen J.P., Nagy J. \& Mørk A. 2008. Lower Cretaceous lithostratigraphy across a regional subaerial unconformity in Spitsbergen: the Rurikfjellet and Helvetiafjellet formations. Norwegian Journal of Geology 88, 287-304.

Miller K.G., Kominz M.A., Browning J.V., Wright J.D., Mountain G.S., Katz M.E., Sugarman P.J., Cramer B. S., Christie-Blick N. \& Pekar S.F. 2005. The Phanerozoic record of global sea-level change. Science 310, 1293-1298.

Mørk A. 1978. Observations on the stratigraphy and structure of the inner Hornsund area. Norsk Polarinstitutt Årbok 1977, 61-70.

Mørk A. \& Smelror M. 2001. Correlation and non-correlation of high order circum-Arctic Mesozoic sequences. Polarforschung 69, 65-72.

Mutrux J., Maher H., Shuster R. \& Hays T. 2008. Iron ooid beds of the Carolinefjellet Formation, Spitsbergen, Norway. Polar Research 27, 28-43.

Mutterlose J. \& Kessels K. 2000. Early Cretaceous calcareous nannofossils from high latitudes: implications for palaeobiogeography and palaeoclimate. Palaeogeography, Palaeoclimatology, Palaeoecology 160, 347-372.

Nagy J. 1970. Ammonite faunas and stratigraphy of Lower Cretaceous (Albian) rocks in southern Spitsbergen. Norsk Polarinstitutt Skrifter 152, 1-58.

Nemec W. 1992. Depositional controls on plant growth and peat accumulation in a braidplain delta environment: Helvetiafjellet Formation (Barremian-Aptian), Svalbard. In P.J. McCabe \& J.T. Parish (eds.): Controls on the distribution and quality of Cretaceous coals. Pp. 209-226. Boulder: Geological Society of America.

Nemec W., Steel R.J., Gjelberg J., Collinson J.D., Prestholm E., Øxnevad I.E. \& Worsley D. 1988. Anatomy of collapsed and re-established delta front in Lower Cretaceous of eastern Spitsbergen: gravitational sliding and sedimentation process. AAPG Bulletin 72, 454-476.

Nøttvedt A. \& Kriesa R.D. 1987. Model for the combinedflow origin of hummocky cross-stratification. Geology 15, 357-361.

Onderdonk N., \& Midtkandal I. 2010. Mechanisms of collapse of the Cretaceous Helvetiafjellet Formation at Kvalvågen, eastern Spitsbergen. Marine and Petroleum Geology 27, 2118-2140.

Paech H.-J. \& Koch J. 2001. Coalification in postCaledonian sediments on Spitsbergen. In F. Tessensohn (ed.): Intra-continental fold belts. Case 1: west Spitsbergen. Pp. 507-530. Hannover: BGR.

Parker J.R. 1967. The Jurassic and Cretaceous sequence in Spitsbergen. Geological Magazine 104, 487-505.

Patruno S., Hampson G.J. \& Jackson C.A.-L. 2015. Quantitative characterisation of deltaic and subaqueous clinoforms. Earth-Science Reviews 142, 79-119.

Plint A.G. \& Nummedal D. 2000. The falling stage systems tract: recognition and importance in sequence stratigraphic analysis. In D. Hunt D. \& R. Gawthorpe (eds.): Sedimentary responses to forced regression. Pp. 1-17. London: Geological Society.

Plint A.G. 1988. Sharp-based shoreface sequences and "offshore bars" in the Cardium Formation of Alberta: their relationship to relative changes in sea-level. In C.K. Wilgus et al. (eds.): Sea-level change-an integrated approach. Pp. 357-370. Tulsa: Society for Sedimentary Geology.

Price G.D. 1999. The evidence and implications of polar ice during the Mesozoic. Earth Science Reviews 48, 183-210.

Price G.D. \& Nunn E.V. 2010. Valanginian isotope variation in glendonites and belemnites from Arctic Svalbard: transient glacial temperatures during the Cretaceous greenhouse. Geology 38, 251-254.

Royer D.L. 2006. $\mathrm{CO}_{2}$-forced climate thresholds during the Phanerozoic. Geochimica et Cosmochimica Acta 70, $5665-5675$.

Ryseth A., Augustson J.H., Charnock M., Haugerud O., Knutsen S.-M., Midbøe P.S., Opsal J.G. \& Sundsbø G. 2003. Cenozoic stratigraphy and evolution of the Sørvestsnaget Basin, southwestern Barents Sea. Norwegian Journal of Geology 83, 107-130.

Schieber J., Southard J. \& Thaisen K. 2007. Accretion of mudstone beds from migrating floccule ripples. Science 318, 1760-1763.

Selleck B.W., Carr P.F. \& Jones B.G. 2007. A review and synthesis of glendonites (pseudomorphs after ikaite) with new data: assessing applicability as recorders of ancient coldwater conditions. Journal of Sedimentary Research 77, 980-991. 
Senger K., Tveranger J., Ogata K., Braathen A. \& Planke S. 2014. Late Mesozoic magmatism in Svalbard: a review. Earth-Science Reviews 139, 123-144.

Sheldon N.D. \& Tabor N.J. 2009. Quantitative paleoenvironmental and paleoclimatic reconstruction using paleosols. Earth-Science Reviews 95, 1-52.

Smelror M. \& Larssen G.B. 2016. Are there Upper Cretaceous sedimentary rocks preserved on Sørkapp Land, Svalbard? Norwegian Journal of Geology 96, 1-12.

Smith D.G., Harland W.B., Hughes N.F. \& Pickton C.A.G. 1976. The geology of Kong Karls Land, Svalbard. Geological Magazine 113, 193-232.

Steel R.J., Crabaugh J., Schellpepper M., Mellere D., PlinkBjörklund P., Deibert J. \& Løseth T. 2000. Deltas vs. rivers on the shelf edge: their relative contributions to the growth of shelf-margins and basin-floor fans (Barremian and Eocene, Spitsbergen). In P. Weimer et al. (eds.): Deep-water reservoirs of the world. Gulf Coast Section Society of Economic Paleontologists and Mineralogists Foundation 20th Annual Bob F. Perkins Research Conference. Pp. 981-1009. Houston: Gulf Coast Section Society of Economic Paleontologists and Mineralogists Foundation.

Steel R.J., Gjelberg J. \& Harr G. 1978. Helvetiafjellet Formation (Barremian) at Festningen, Spitsbergen-a field guide. Norsk Polarinstitutt Årbok 1978, 111-128.

Steel R.J. \& Worsley D. 1984. Svalbard's post-Caledonian strata-an atlas of sedimentational patterns and palaeogeographic evolution. In A.M. Spencer (ed.): Petroleum geology of the North European Margin. Pp. 109-135. London: Norwegian Petroleum Society /Graham \& Trotman.
Suess E., Balzer W., Hesse K.F., Müller P.J. \& Wefer G. 1982. Calcium carbonate hexahydrate from organic-rich sediments of the Antarctic shelf: precursor of glendonites. Science 1216, 1128-1131.

Taylor A.M. \& Goldring R. 1993. Description and analysis of bioturbation and ichnofabric. Journal of Geological Society London 150, 141-148.

Throndsen T. 1982. Vitrinite reflectance studies of coals and dispersed organic matter in Tertiary deposits in the Adventdalen area, Svalbard. Polar Research 2, 77-91.

Torsvik T.H., Carlos D., Mosar J., Cocks L.R.M. \& Malme T.N. 2002. Global reconstructions and North Atlantic paleogeography $440 \mathrm{Ma}$ to Recent. In Eide E.A. (ed): BATLAS. Mid Norway plate reconstruction atlas with global and Atlantic perspective. Pp. 18-39. Trondheim: Geological Survey of Norway.

Tyrrell G.W. \& Sandford K.S. 1933. Geology and petrology of the dolerites of Spitsbergen. Proceedings of the Royal Society of Edinburgh 53, 284-321.

Van Wagoner J.C., Mitchum R.M., Campion K.M. \& Rahmanian V.D. 1990. Siliciclastic sequence stratigraphy in well logs, cores, and outcrops: concepts for high resolution correlation of time and facies. Methods in Exploration Series 7. Tulsa: American Association of Petroleum Geologists.

Worsley D. 1986. The geological history of Svalbard: evolution of an Arctic archipelago. Stavanger: Norwegian State Oil Company.

Ziegler P.A. 1988. Evolution of the Arctic-North Atlantic and the western Tethys. Tulsa: American Association of Petroleum Geologists. 